\title{
Observations of reactive nitrogen oxide fluxes by eddy covariance above two midlatitude North American mixed hardwood forests
}

\author{
J. A. Geddes and J. G. Murphy \\ Department of Chemistry, University of Toronto, 80 St. George St., Toronto, ON M5S 3H6, Canada
}

Correspondence to: J. G. Murphy (jmurphy@chem.utoronto.ca)

Received: 22 September 2013 - Published in Atmos. Chem. Phys. Discuss.: 29 October 2013

Revised: 31 January 2014 - Accepted: 4 February 2014 - Published: 21 March 2014

\begin{abstract}
Significant knowledge gaps persist in the understanding of forest-atmosphere exchange of reactive nitrogen oxides, partly due to a lack of direct observations. Chemical transport models require representations of dry deposition over a variety of land surface types, and the role of canopy exchange of $\mathrm{NO}_{\mathrm{x}}\left(=\mathrm{NO}+\mathrm{NO}_{2}\right)$ is highly uncertain. Biosphere-atmosphere exchange of $\mathrm{NO}_{\mathrm{x}}$ and $\mathrm{NO}_{\mathrm{y}}$ $\left(=\mathrm{NO}_{\mathrm{x}}+\mathrm{HNO}_{3}+\mathrm{PANs}+\mathrm{RONO}_{2}+p \mathrm{NO}_{3}^{-}+\ldots\right)$ was measured by eddy covariance above a mixed hardwood forest in central Ontario (Haliburton Forest and Wildlife Reserve, or HFWR), and a mixed hardwood forest in northern lower Michigan (Program for Research on Oxidants: Photochemistry, Emissions and Transport, or PROPHET) during the summers of 2011 and 2012 respectively. $\mathrm{NO}_{\mathrm{x}}$ and $\mathrm{NO}_{\mathrm{y}}$ mixing ratios were measured by a custom-built two-channel analyser based on chemiluminescence, with selective $\mathrm{NO}_{2}$ conversion via $\mathrm{LED}$ photolysis and $\mathrm{NO}_{\mathrm{y}}$ conversion via a hot molybdenum converter. Consideration of interferences from water vapour and $\mathrm{O}_{3}$, and random uncertainty of the calculated fluxes are discussed. $\mathrm{NO}_{\mathrm{y}}$ flux observations were predominantly of deposition at both locations. In general, the magnitude of deposition scaled with $\mathrm{NO}_{\mathrm{y}}$ mixing ratios. Average midday (12:00-16:00) deposition velocities at HFWR and PROPHET were $0.20 \pm 0.25$ and $0.67 \pm 1.24 \mathrm{~cm} \mathrm{~s}^{-1}$ respectively. Average nighttime (00:00-04:00) deposition velocities were $0.09 \pm 0.25 \mathrm{~cm} \mathrm{~s}^{-1}$ and $0.08 \pm 0.16 \mathrm{~cm} \mathrm{~s}^{-1}$ respectively. At HFWR, a period of highly polluted conditions $\left(\mathrm{NO}_{\mathrm{y}}\right.$ concentrations up to $18 \mathrm{ppb}$ ) showed distinctly different flux characteristics than the rest of the campaign. Integrated daily average $\mathrm{NO}_{\mathrm{y}}$ flux was $-0.14 \mathrm{mg}(\mathrm{N}) \mathrm{m}^{-2}$ day $^{-1}$ and $-0.34 \mathrm{mg}(\mathrm{N}) \mathrm{m}^{-2}$ day $^{-1}$ (net deposition) at HFWR and PROPHET respectively. Concurrent wet deposition measurements were used to estimate the contributions of dry deposi-
\end{abstract}

tion to total reactive nitrogen oxide inputs, found to be 22 and $40 \%$ at HFWR and PROPHET respectively.

\section{Introduction}

Emissions of $\mathrm{NO}_{\mathrm{x}}$ from both anthropogenic and biogenic sources control tropospheric ozone production and the oxidizing capacity of the atmosphere through reactions involving hydrocarbons and $\mathrm{OH}$ radicals. The oxidation of $\mathrm{NO}_{\mathrm{x}}$ to other species leads to particle formation and deposition of nitrogen, potentially far from sources where ecosystems can be disrupted by the additional nutrients (Vitousek et al., 1997; Galloway et al., 2003).

Forests cover about $30 \%$ of the Earth's land surface and influence climate through evapotranspiration, albedo effects, and carbon sequestration, but the net climate forcing from these is not well known (Bonan, 2008). Even less is understood about how nitrogen cycling and trace gas exchanges at the surface impact the atmospheric chemistry and carbon storage potential of forests. Nitrogen deposition from anthropogenic activities is postulated to have increased carbon uptake of forests across the Northern Hemisphere (Magnani et al., 2007; Thomas et al., 2010), but may also have detrimental effects at high levels (Vitousek et al., 1997). The recent rapid decline of $\mathrm{NO}_{\mathrm{x}}$ emissions across most of North America and Europe motivated by air quality concerns is expected to have important consequences on the deposition of nitrogen to sensitive ecosystems. A decline in forest carbon uptake due to a weakening of the nitrogen fertilization effect would have implications for future climate predictions (Templer et al., 2012). It is therefore important to calculate accurate nitrogen deposition budgets in these changing environments. 
Nitrogen is deposited out of the atmosphere by both wet and dry deposition. Nitrogen deposition budgets are generally calculated using two approaches: (1) by combining wet deposition observations across a network of precipitation sampling sites with dry deposition estimates inferred from a dry deposition model, forced by observed ambient concentrations at those sampling sites and observed meteorology; or (2) by fully modelling deposition using a chemical transport model driven by meteorology and emission estimates. Estimates of nitrogen deposition therefore depend on models with accurate surface and micrometeorological parameters, and sufficient observations (or adequate modelling) of all the relevant species. However, due to a lack of direct observations, dry deposition model parameterizations are based on limited data sets and unconfirmed assumptions (Wesely and Hicks, 2000; Flechard et al., 2011). Moreover, mixing ratio observations are sparse and are rarely available for all the necessary species, requiring spatial interpolation and assumptions about the unknown contributions (Holland et al., 2005).

Using the former approach applied to the US and Europe, dry deposition was calculated to contribute $40-60 \%$ of total $\mathrm{NO}_{\mathrm{y}}$ deposition, although this only includes contributions from $\mathrm{HNO}_{3(\mathrm{~g})}$ and particulate nitrate in the US, and $\mathrm{HNO}_{3(\mathrm{~g})}$, particulate nitrate, and $\mathrm{NO}_{2}$ in Europe (Holland et al., 2005). Given the potential contribution of species other than nitrate (and $\mathrm{NO}_{2}$ ) to deposition, and frequent placement of deposition monitoring sites at remote locations, these are likely underestimates. At several locations across Canada, a deposition model that was applied to short-term measurements of individual $\mathrm{NO}_{\mathrm{y}}$ species estimated that dry deposition of nonnitrate species contributes equally or significantly more at every site (Zhang et al., 2009). At a site in North Carolina, nitrate was estimated not to be the dominant deposited species (Sparks et al., 2008). Similarly, at Harvard Forest, MA, nitric acid was estimated to contribute between 38 and $73 \%$ of the total gaseous $\mathrm{NO}_{\mathrm{y}}$ flux, with $\mathrm{NO}_{\mathrm{x}}$ only partly compensating for the rest (Horii et al., 2006). Fully simulated deposition across the US using GEOS-Chem concluded that dry deposition contributes around $70 \%$ of total $\mathrm{NO}_{\mathrm{y}}$ deposition, with most significant contributions from $\mathrm{HNO}_{3(\mathrm{~g})}$, $\mathrm{NO}_{2}$, isoprene nitrates, and peroxyacetyl nitrate, in that order (Zhang et al., 2012). The contribution of dry deposition to total deposition generally decreases with distance from source regions.

Exchange above forest canopies is affected by atmospheric inputs, surface emissions, and complex canopy interactions. $\mathrm{NO}_{2}$ deposition can be offset by below-canopy soil NO emissions that are rapidly converted to $\mathrm{NO}_{2}$ (Wesely and Hicks, 2000). Uncertainties in the extent, and subsequent canopy losses (through chemistry and uptake), of primary soil NO emissions can confound modelling efforts (Ganzeveld et al., 2002). It is also unclear whether emission or deposition of $\mathrm{NO}_{2}$ at leaf surfaces may be driven by a compensation point mechanism (Lerdau et al., 2000; Sparks et al., 2001; Chaparro-Suarez et al., 2011). It has also been suggested that photolysis of nitric acid on forest canopy surfaces leads to an upward flux of HONO (Zhou et al., 2011). Forests may therefore be sinks or sources of $\mathrm{NO}_{\mathrm{x}}$ depending not only on proximity to anthropogenic sources and the strength of local soil emissions, but also a combination of other counteracting mechanisms which are not well characterized by observations.

A further consequence of the above is that it is difficult to elucidate actual emission and deposition of individual reactive nitrogen oxides at the surface-atmosphere interface from above-canopy observations. Here, we make use of the assumption that $\mathrm{NO}_{\mathrm{y}}$ is a chemically conserved species, implying therefore that observed downward fluxes are of true deposition. However, for individual species such as $\mathrm{NO}$ and $\mathrm{NO}_{2}$ (and possibly even their sum, $\mathrm{NO}_{\mathrm{x}}$ ), the observed fluxes are referred to either as "downward" or "upward" fluxes. How these relate to emission and deposition at the surfaceatmosphere interface requires careful consideration.

Here we present results from two campaigns where mixing ratios and fluxes of $\mathrm{NO}_{\mathrm{y}}$ were measured by eddy covariance at two comparable North American mixed forests located along the same latitude $\left(45^{\circ} \mathrm{N}\right)$. While measurements of total $\mathrm{NO}_{\mathrm{y}}$ were made, simultaneous $\mathrm{NO}$ and $\mathrm{NO}_{2}$ mixing ratios were also measured. Shorter-term eddy covariance measurements of $\mathrm{NO}_{\mathrm{x}}$ flux were also performed at each site to help elucidate the role of the forests as net sinks or sources of $\mathrm{NO}_{\mathrm{x}}$. In this paper, the focus is on reporting the instrumental methods, summarizing the observations, discussing the results in the context of quantifying a total oxidized nitrogen deposition budget (by incorporating observations from national wet deposition monitoring networks) and identifying the influence of atmospheric transport. Results are compared to other $\mathrm{NO}_{\mathrm{y}}$ flux observations previously reported above forests across eastern North America.

\section{Experimental}

\subsection{Sites}

Observations were made from 20 July to 11 October 2011 at Haliburton Forest and Wildlife Reserve (HFWR; $45^{\circ} 17^{\prime} 11^{\prime \prime} \mathrm{N}, 78^{\circ} 32^{\prime} 19^{\prime \prime} \mathrm{W}$ ), located in central Ontario, and from 24 July to 14 August 2012 at the University of Michigan Biological Station (UMBS; 45 $33^{\prime} 32^{\prime \prime} \mathrm{N}, 84^{\circ} 42^{\prime} 52^{\prime \prime} \mathrm{W}$ ), located in northern Michigan. Both forests are characterized as mixed, marking the transition between deciduous forests to the south and the coniferous forests to the north. The location of both sites is shown in Fig. 1 .

HFWR is privately owned land managed under selection system silviculture resulting in a mixed-age canopy, with last harvesting near the tower site in 1997. The dominant species is sugar maple, with contributions from American beech, yellow birch, eastern hemlock and eastern white pine. Measurements were made from the top of a $32 \mathrm{~m}$ tower, where the 


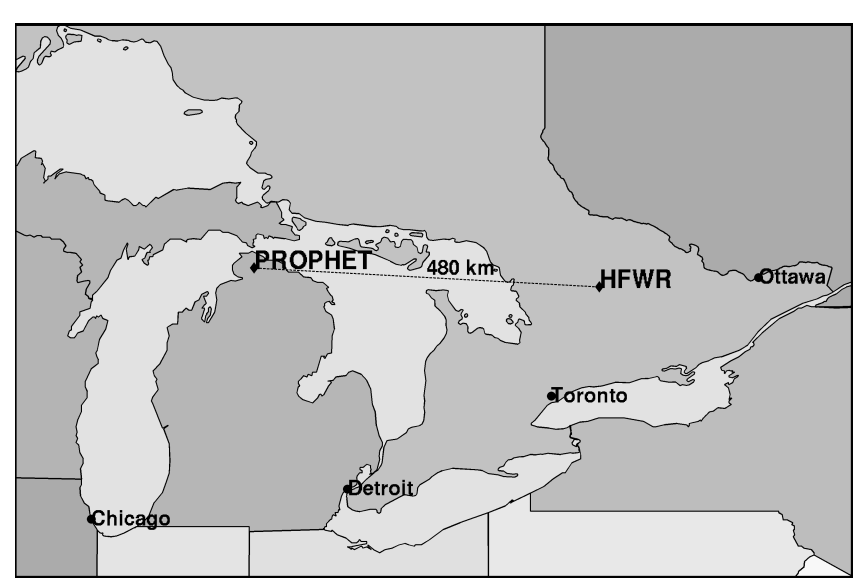

Fig. 1. Locations of PROPHET and HFWR towers.

average canopy is $20-25 \mathrm{~m}$ high. UMBS is located approximately $500 \mathrm{~km}$ directly to the west of HFWR. Measurements were made from the $30 \mathrm{~m}$-tall Program for Research on Oxidants: Photochemistry, Emissions and Transport (PROPHET; see Carroll et al., 2001) tower. The site is a secondary successional forest last disturbed by fire in 1923, with a mean canopy height of around $22 \mathrm{~m}$. The dominant species here are bigtooth aspen and trembling aspen, with contributions from red maple and sugar maple, red oak, birch, beech, and white pine. The PROPHET tower is situated about $100 \mathrm{~m}$ to the south of an established AmeriFlux tower (Schmid et al., 2003).

\subsection{Mixing ratios of $\mathrm{NO}, \mathrm{NO}_{2}, \mathrm{NO}_{\mathrm{y}}$, and $\mathrm{O}_{3}$}

Nitrogen oxides were measured by a custom-built dualchannel chemiluminescence instrument from Air Quality Design Inc. (www.airqualitydesign.com). This instrument is similar to the $\mathrm{NO}_{\mathrm{x}}$ instruments used in Lee et al. (2009) and Reidmiller et al. (2010) in that $\mathrm{NO}_{2}$ conversion is based on a blue LED converter documented by Buhr (2007). $\mathrm{NO}_{\mathrm{y}}$ conversion is achieved by passing the sample flow through a hot molybdenum oxide converter (MoC). This converter is identical to that described in the Environmental Science and Engineering (ESE) instrument reported by Williams et al. (1998). An alternative method for the conversion of $\mathrm{NO}_{\mathrm{y}}$ is the gold tube converter (among other metal and alloy converter tubes that have been tested, such as platinum, nickel, and stainless steel; Fahey et al., 1985; Kliner et al., 1997), usually heated in the presence of a reducing gas such as $\mathrm{CO}$ or $\mathrm{H}_{2}$. Comparisons of $\mathrm{NO}_{\mathrm{y}}$ conversion by Mo or Au converters have been discussed in the literature (e.g. Williams et al., 1998), in addition to studies comparing multiple Mo converters with themselves (e.g. Fitz et al., 2003; Xue, et al., 2011). Differences in $\mathrm{NO}_{\mathrm{y}}$ conversion between the conventional techniques have been reported to be within $5 \%$, and with an adequate quality control program should not result in significant differences. Critically, there is consensus that non- $\mathrm{NO}_{\mathrm{y}}$ interferences (e.g. $\mathrm{NH}_{3}$ ) and ideal operating temperatures must be assessed for each instrument individually under the relevant conditions. In the present work, the $\mathrm{MoC}$ was operated at a set temperature of $300^{\circ} \mathrm{C}$. The conversion efficiency for our system was tested for $\mathrm{NO}_{2}, \mathrm{HNO}_{3}$, and $\mathrm{NH}_{3}$ before and after the campaigns. Conversion of $\mathrm{NO}_{2}$ and $\mathrm{HNO}_{3}$ was found to be within $10 \%$ of unity, while the $\mathrm{NH}_{3}$ interferences were less than $30 \%$ and less than $10 \%$ at HFWR and PROPHET respectively.

Time response through the inlet system of problematic compounds such as $\mathrm{HNO}_{3}$ must be considered. The converters are located in a detachable inlet component in order to minimize sampling losses, and components of the inlet made of steel are silco-coated in order to improve transmission. Lab tests were performed to determine the instrument time response. By alternating ambient sampling with zero air overflow at the inlet, the decrease in signal was well represented by exponential decay with a $1 \mathrm{~s}$ time constant. However, in experiments where the instrument was exposed to prolonged (hours) high $\mathrm{HNO}_{3}$ concentrations from an $\mathrm{HNO}_{3}$ permeation device, the decrease in signal was well represented by a bi-exponential decay, with a fast time constant governed by the overall time response ( $1 \mathrm{~s})$, and a slower time constant around 1-2 min. In our $\mathrm{HNO}_{3}$ experiments, the amplitude of the fast decay was more significant than the amplitude of the slow decay. These results are broadly similar to the experiments reported for $\mathrm{NO}_{\mathrm{y}}$ flux measurements by gold catalyst converter (Munger et al., 1996). Problematic fast sampling of $\mathrm{HNO}_{3}$ has also been reported elsewhere (e.g. Horii et al., 2006), so that $\mathrm{HNO}_{3}$ fluxes in eddy covariance observations of $\mathrm{NO}_{\mathrm{y}}$ may be underrepresented. Based on our experiments, and the cospectra presented in Sect. 2.3.3 that suggest most of the flux at each site was dominated by eddies of frequencies less than $0.1 \mathrm{~Hz}$, we expect that there may be some underestimate of the $\mathrm{HNO}_{3}$ fluxes at each site.

The inlet is connected to the calibration and detection systems by a weather-proof umbilical of approximately $40 \mathrm{~m}$, which houses sampling lines, calibration input lines, ethernet cables, and power lines. Chemiluminescence is measured in $200 \mathrm{~mL}$ reaction chambers that are each kept at a pressure of 5.5 torr. It is well known that ozone can react with olefin species to produce excited ketones that may chemiluminesce and could conceivably interfere with NO measurements. However, since species such as formaldehyde and glyoxal have an emission peak below $600 \mathrm{~nm}$ (Finlayson et al., 1974; Hills and Zimmerman, 1990), we minimize these interferences by using a glass red filter blocking wavelengths less than $610 \mathrm{~nm}$. We are unable to account for potential interferences that occur at longer wavelengths.

The inlet was designed to be operated in two modes: (1) continuous $\mathrm{NO}_{\mathrm{x}}-\mathrm{NO}$ mode, where channel 1 continuously samples $\mathrm{NO}_{\mathrm{x}}$ by leaving the $\mathrm{NO}_{2}$ converter on, while channel 2 continuously samples NO by bypassing the MoC; and (2) alternating $\mathrm{NO} / \mathrm{NO}_{\mathrm{x}}$-continuous $\mathrm{NO}_{\mathrm{y}}$ mode, where channel 1 alternates between $\mathrm{NO}$ and $\mathrm{NO}_{\mathrm{x}}$ by switching the $\mathrm{NO}_{2}$ 
converter on and off, while channel 2 continuously samples $\mathrm{NO}_{\mathrm{y}}$ through the MoC. No filtering for particles as components of $\mathrm{NO}_{\mathrm{y}}$ was used (although a filter is located immediately following the $\mathrm{MoC}$ converter to avoid possible debris contacting the mass flow controllers).

Measurements were conducted on a 30 min cycle, with $30 \mathrm{~s}$ of "dark count" measurements (see below) for background corrections followed by $29.5 \mathrm{~min}$ of ambient sampling. Calibrations were performed every $5-7 \mathrm{~h}$ during the campaigns, by standard addition of $\mathrm{NO}$ over ambient air. For the HFWR campaign, the NO standard used was a BOCLinde cylinder of $5 \mathrm{ppm} \mathrm{NO}( \pm 10 \%)$ in $\mathrm{N}_{2}$. For the PROPHET campaign, the standard used was a cylinder of $5.17 \mathrm{ppm} \mathrm{NO}( \pm 5 \%)$ in $\mathrm{N}_{2}$. Dilution flow into the sample air was controlled by a mass flow controller (Pneucleus Technologies LLC) with a trim pot that was adjusted to either 5.30 or $7.05 \mathrm{sccm} . \mathrm{NO}_{2}$ conversion efficiency of the LED converter and the $\mathrm{MoC}$ could be tested throughout the campaign by titrating approximately half of the calibration $\mathrm{NO}$ with $\mathrm{O}_{3}$. Controlled in-lab conversion efficiency experiments before and after the campaign were also performed. In addition to the uncertainty in the standards, uncertainty in the mixing ratios due to random error $(3 \sigma)$ during calibrations was less than $5 \%$ for $\mathrm{NO}$ and $\mathrm{NO}_{\mathrm{y}}$ during both campaigns, but 19.2 and $11.1 \%$ for $\mathrm{NO}_{2}$ during the HFWR and PROPHET campaigns respectively, due to conversion efficiency calculations. Adding the random errors in quadrature, the total error in $\mathrm{NO}$ and $\mathrm{NO}_{2}$ were \pm 11 and $\pm 22 \%$ respectively at HFWR, and \pm 7 and $\pm 12 \%$ at PROPHET. The total error for $\mathrm{NO}_{\mathrm{y}}$ at HFWR and PROPHET was $\pm 11 \%$ and $\pm 7 \%$ respectively, with a systematic underestimate of up to $+10 \%$ as a result of the conversion efficiency.

Throughout the campaigns, the inlet was used most in mode 2, allowing for simultaneous measurements of $\mathrm{NO}$ and $\mathrm{NO}_{2}$ mixing ratios (by interpolation), and continuous $\mathrm{NO}_{\mathrm{y}}$ mixing ratios. Since $\mathrm{NO}_{\mathrm{y}}$ observations went uninterrupted for $29.5 \mathrm{~min}$ at a time, eddy covariance $\mathrm{NO}_{\mathrm{y}}$ fluxes could be calculated. When operating in mode 1 (for 3 non-continuous weeks and 5 consecutive days at HFWR and PROPHET respectively), eddy covariance $\mathrm{NO}_{\mathrm{x}}$ fluxes could be calculated. Consistency between the two channels could be tested throughout the campaigns when channel 2 bypassed the MoC (mode 1), and the $\mathrm{NO}_{2}$ converter in channel 1 was left off for first $30 \mathrm{~s}$ of sampling after dark counts. This allowed for simultaneous detection of NO in both channels once every $30 \mathrm{~min}$. From these tests, NO mixing ratios in channel 1 and channel 2 were indistinguishable (e.g. at HFWR, slope of least orthogonal distance regression of $0.975 \pm 0.003$, Pearson's $R^{2}=0.995$ ), within the random error of the individual calibrations $(<3.5 \%$ on average).

The instrument ran with data collection at $5 \mathrm{~Hz}$. The detection limits (signal-to-noise ratio of 3) for $\mathrm{NO}, \mathrm{NO}_{2}$, and $\mathrm{NO}_{\mathrm{y}}$ were around 30,120 , and $30 \mathrm{ppts}^{-1}$ respectively. Backgrounds and chemical interferences (dark counts) were determined by mixing the sample air with $\mathrm{O}_{3}$ upstream of the main reactor. These counts were subtracted from the main chamber signal at other times (based on linear interpolation between tests). Zero air from a Sabio 1001P compressed air generator was also used to test for artefacts; however the response from this was occasionally above ambient signals at both HFWR and PROPHET, and was therefore not subtracted from the signal. At PROPHET, after correcting for dark counts, nighttime NO mixing ratios were usually below the detection limit, so no further corrections were applied. At HFWR, artefacts not accounted for in the dark counts were determined by subtracting the minimum observed NO over each night (mean $\pm 1 \sigma=59 \mathrm{ppt} \pm 50 \mathrm{ppt}$ ), interpolated between each day. This assumes that deviations from the expected value of close to zero at night were due to the instrument, and incorrectly account for artefacts if the interferences have a diurnal profile. Similar procedures have been applied elsewhere (e.g. Lee et al., 2009). The half-hour mean $\mathrm{O}_{3}$ concentrations at midnight were $27 \mathrm{ppb}$ (on average, $\mathrm{O}_{3}$ reached a minimum of $23 \mathrm{ppb}$ around 07:30 local time (LT)). These concentrations are sufficiently high that NO would likely have been titrated overnight.

At HFWR, a generator located $100 \mathrm{~m}$ northeast (usually downwind) was required to power the instruments. This resulted in observable spikes in the $\mathrm{NO}_{\mathrm{x}}$ and $\mathrm{NO}_{\mathrm{y}}$ time series. In most cases, these times were easily identified manually and removed in post-processing. After initial manual identification, other spikes (whether due to the generator or not) were identified by a technique based on the median of absolute deviation about the median, performed on the doubledifferenced time series with a 7-day running window. This method has been used previously for identifying spikes in half-hour eddy covariance fluxes (Papale et al., 2006), but it was also deemed to perform well for this purpose as opposed to filtering based on a running standard deviation. From the whole campaign, approximately $30 \%$ of the data was removed.

Ozone was monitored at the same height as $\mathrm{NO}_{\mathrm{x}}$ and $\mathrm{NO}_{y}$ during both campaigns by a commercial $\mathrm{O}_{3} \mathrm{UV}$ analyser (Thermo model 49C), sampled every $10 \mathrm{~s}$ (precision of $1 \mathrm{ppb})$.

\subsection{Eddy covariance fluxes of $\mathrm{NO}_{x}$ and $\mathrm{NO}_{\mathrm{y}}$}

The eddy covariance flux of a chemical species crossing a horizontal plane at instrument height is calculated as the covariance between instantaneous deviations of wind speed and the species mixing ratio relative to an averaging period:

$F_{c}=\frac{1}{n} \sum_{i=1}^{n}\left[\left(w_{i}-\bar{w}\right) \cdot\left(c_{i}-\bar{c}\right)\right]$,

where $n$ is the number of points per averaging period, $w$ is vertical wind speed, and $c$ is the mixing ratio of the species of interest (the subscript $i$ represents the instantaneous measurement, while the overbar denotes the mean for the averaging period). In the present study, fluxes are calculated for 
half-hour averaging periods, and the mean vertical wind was minimized by applying the planar fit correction approach presented by Wilczak et al. (2001).

Analogue signals from the instrument were directed to a CR3000 datalogger that was collecting the wind measurements from the sonic anemometer at $10 \mathrm{~Hz}$. For the purposes of flux calculations, the analogue signal could be used to perfectly synchronize the observations from the instrument with the data from the sonic anemometer (the analogue signals from the instrument collected by the datalogger were not used directly for the flux calculation since it was not possible to $\log$ important valve states (calibration times, zeros) due to a lack of analogue outputs from the instrument). The data were resynchronized in 5- to 7-day chunks, and the instrument and datalogger clocks were found to drift approximately 3 to $4 \mathrm{~s}$ during this length of time. It was assumed that the lag-time calculation (see immediately below) corrected for this component of drift.

The intake line for $\mathrm{NO}_{\mathrm{x}}$ and $\mathrm{NO}_{\mathrm{y}}$ sampling was $60 \mathrm{~cm}$ away from the sonic anemometer. Sampling flow rate in each channel was $1.5 \mathrm{~L} \mathrm{~min}^{-1}$, through tubing of $0.062^{\prime \prime}$ inner wall diameter. The time lag between an observation of wind made by the sonic anemometer and the $\mathrm{NO}_{\mathrm{x}}$ or $\mathrm{NO}_{\mathrm{y}}$ mixing ratios in that same parcel of air must be accounted for due to this sensor separation, in addition to transit time in the long sampling lines of the $\mathrm{NO}_{\mathrm{y}}$ instrument. This was performed by determining maximum correlation between $w^{\prime}$ and $\mathrm{NO}_{\mathrm{y}}^{\prime}$ in a lag-correlation plot every half hour. Figure 2 shows an average of this calculation compared to the average lag plot for $\mathrm{CO}_{2}$ which was also measured during the campaign by an open path infrared gas analyser for $\mathrm{CO}_{2}$ fluxes.

For eddy covariance to be valid, the assumption of stationary flow must be satisfied, and this can be tested for using the method proposed by Foken and Wichura (1996). In this approach, half-hour covariances are compared to the mean of the covariances calculated in six consecutive 5 min windows within each half hour. Half hours when these two quantities differed by greater than $40 \%$ were removed from the analysis. During HFWR, 33 and $21 \%$ of the $\mathrm{NO}_{\mathrm{y}}$ and $\mathrm{NO}_{\mathrm{x}}$ flux observations respectively were removed due to failing this stationarity test. During PROPHET, 46 and $33 \%$ of the $\mathrm{NO}_{\mathrm{y}}$ and $\mathrm{NO}_{\mathrm{x}}$ flux observations were removed respectively. We do not apply any $u_{*}$ filter to the reactive nitrogen oxide fluxes.

Corrections for flow distortion identified by integral turbulence statistics (e.g. $\sigma_{w} / u_{*}$ ) due to the influence of the tower required the removal of data from wind directions between 0 and $93^{\circ}$ at HFWR. At this location, wind from this direction tends to represent unpolluted conditions, and therefore removing this data introduces a possible selection bias. However, of the data left after other quality assurance/quality control steps, only an additional 3-4\% of the data was removed. No such removal of data was required for the PROPHET data set.

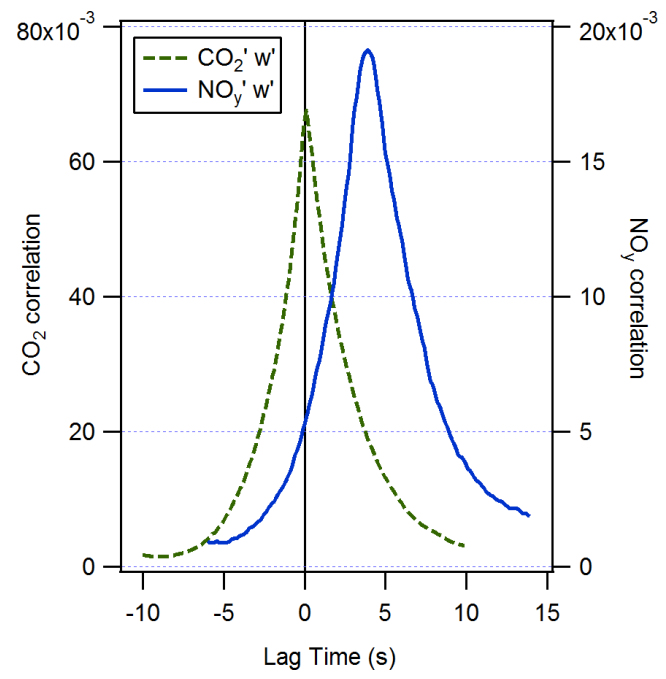

Fig. 2. Average lagged correlation plot to determine the true lag between $\mathrm{NO}_{\mathrm{y}}$ sensor response and vertical wind $\left(w^{\prime}\right)$ observations. Also shown is the lagged correlation plot for $w^{\prime} \mathrm{CO}_{2}^{\prime}$.

\subsubsection{Flux interferences}

The calculation of a scalar flux by eddy covariance can be affected by interferences from covarying scalars such as temperature and water vapour, if those scalars affect the density of air or the response of the instrument.

The Webb, Pearman, and Leuning (WPL) correction (Webb et al., 1980) accounts for the effect of temperature and water on air density fluctuations. In closed-path instruments and/or in cases when temperature is held constant, fluctuations in air temperature are unimportant, but Eq. (22) of Webb et al. (1980) shows how fluctuations in water vapour may still cause errors:

$F_{c}=\bar{\rho}\left[\overline{w^{\prime} c^{\prime}}+\{\bar{c} /(1-q)\} \overline{w^{\prime} q^{\prime}}\right]$,

where $\rho$ is the density of moist air, $c$ is the scalar $\left(\mathrm{NO}_{\mathrm{y}}\right)$, and $q$ is the specific humidity. The ' represents the instantaneous deviation from the $30 \mathrm{~min}$ mean of the observation. The first term in the square parentheses represents the measured halfhour covariance of vertical wind and mixing ratio, while the next term in the parentheses represents the correction that must be applied, which is a function of the average mixing ratio, specific humidity, and water vapour flux. In several previous examples of reactive nitrogen oxide fluxes by eddy covariance, this correction is ignored by finding or assuming that it is negligible (Munger et al., 1996; Farmer et al., 2006; Turnipseed et al., 2006). Colocated latent heat fluxes were measured at HFWR during the campaign, and at a flux tower close to PROPHET during that campaign, so estimates of this correction term could be calculated. Because water vapour was not measured in the closed-path reaction cell, we made this estimate by assuming there is no dampening of the water vapour flux (measured by an open path sensor) within 
our instrument tubing. Thus, the estimate of this correction term will be an overestimate of the true correction required (if dampening of $\mathrm{H}_{2} \mathrm{O}$ is similar to dampening of $\mathrm{NO}$, this would result in water fluxes overestimated on the order of $10 \%$; see below). Using Eq. (22) of Webb et al. (1980), we found that for a large majority of the data the correction term would be less than $1 \%$ of the measured covariance. This term becomes largest during the daytime when the evapotranspiration of water is highest (approaching 0.18 and $0.15 \mathrm{ppt} \mathrm{m} \mathrm{s}^{-1}$ on average at PROPHET and HFWR respectively). When the correction term approaches $10 \%$, the fluxes were almost always below the detection limit (discussed below).

As pointed out by Ammann et al. (2012), the chemiluminescent reaction on which the detection of reactive nitrogen oxides is based is sensitive to water vapour, which acts as a quencher and could therefore also lead to an artificial component of the flux. Previous lab studies with the instrument used here showed a linear reduction in sensitivity of about 0.6 and $0.7 \%$ per $\mathrm{g} \mathrm{m}^{-3}$ of water vapour increase in channel 1 and channel 2 respectively. Using the $\mathrm{H}_{2} \mathrm{O}$ flux data again an estimate of the correction term can be made. Like the WPL correction, this estimated correction term reaches an absolute maximum during the daytime $\left(0.79\right.$ and $0.67 \mathrm{ppt} \mathrm{m} \mathrm{s}^{-1}$ on average), about 4-5 times larger than the estimated WPL correction term (consistent with what was found by Ammann et al., 2012). It can therefore become important (> 5\% of the calculated flux); if only the fluxes above the detection limit are considered, about $12 \%$ of the data have correction terms greater than $5 \%$.

To the above interferences we add the consideration of the $\mathrm{NO}+\mathrm{O}_{3}$ back reaction within the sampling lines, which affects the amount of NO that is detected in the reaction chambers. The back reaction is observed when sampling $\mathrm{NO}$ or $\mathrm{NO}_{2}$, but is not applicable to measurements of $\mathrm{NO}_{y}$ since $\mathrm{O}_{3}$ is destroyed in the MoC. While average mixing ratios can be corrected by using colocated $\mathrm{O}_{3}$ mixing ratio observations, high-frequency fluctuations $(>0.1 \mathrm{~Hz})$ in ozone, which may covary with the fluxes of reactive nitrogen oxides, could not be measured by the ozone instrument used in this study. A rough estimate of this term is therefore calculated given previously measured $\mathrm{O}_{3}$ deposition observations at PROPHET and at a similar site, Harvard Forest. Calibrations throughout the campaigns could be used to determine the sensitivity of the $\mathrm{NO}+\mathrm{O}_{3}$ back reaction to ambient $\mathrm{O}_{3}$ mixing ratios since calibrations were performed as standard additions over ambient air. Again, the absolute magnitude of this correction term reaches a maximum during the daytime, which we expect would co-occur with maxima in $\mathrm{H}_{2} \mathrm{O}$ fluxes due to the fact that $\mathrm{O}_{3}$ fluxes are similarly controlled by stomatal opening (Hogg, 2007). However, the sign of this correction term is opposite to the water correction term. While both $\mathrm{O}_{3}$ and $\mathrm{H}_{2} \mathrm{O}$ affect the response of NO in a similar way (decreasing "sensitivity" with increasing concentrations), the flux of $\mathrm{O}_{3}$ is opposite to the flux of water. Given an average $\mathrm{O}_{3}$ deposition flux of about $40 \mu \mathrm{molm}^{-2} \mathrm{~h}^{-1}$ (Munger et al., 1996; Hogg,
2007), the correction term is estimated to be $0.41 \mathrm{pptm} \mathrm{s}^{-1}$ for measurements of $\mathrm{NO}_{\mathrm{x}}$ fluxes.

These considerations illustrate how, beyond the instrumental challenges of measuring reactive nitrogen oxide fluxes, the interpretation of their results remains even more challenging. The average diurnal pattern of the estimated correction terms for the PROPHET campaign is shown in Fig. 3. Since actual correction terms could not be calculated because $\mathrm{H}_{2} \mathrm{O}$ is not measured within the reaction chamber and fastenough ozone measurements could not be made, we do not apply any correction to the measurements, arguing that (1) the estimated correction terms are an overestimate because we have calculated them assuming no dampening within the sample tubing and (2) in the case of $\mathrm{NO}$ and $\mathrm{NO}_{2}$ the water and ozone correction terms have shown to be of similar magnitudes but opposite signs. However, in the case of $\mathrm{NO}_{\mathrm{y}}$ fluxes, the water correction term may result in a systematic artificial deposition component during the daytime as illustrated in Fig. 3.

Finally, we note the additional potential interference as a result of the chemiluminescence from ozonolysis of hydrocarbon species at wavelengths longer than $610 \mathrm{~nm}$. We are unable to account for this interference, although it may be worth investigation in future work.

\subsubsection{Random uncertainty}

Random uncertainty for the half-hour fluxes were estimated using two approaches. First, for both campaigns, a technique based on a minimum lag-correlation calculation was used. For each half hour, the maximum covariance between the scalar of interest and vertical wind is calculated to correct for time-lag effects (see above). This measurement is assumed to be the "true" covariance for that half hour. Then, a "zero" covariance is calculated by introducing a constant delay to the scalar wave and recalculating the covariance. Analyses were done for lags of $20 \mathrm{~s}$ and $60 \mathrm{~s}$. The assumption here is that at these time points, true covariance between $w^{\prime}$ and the scalar is minimized (illustrated in the lag-correlation plot of Fig. 2) and can therefore be used as an estimate of zero flux. Any covariance that results is therefore assumed to be due to instrument noise and other error. If the error is random, an average over multiple observations should be close to zero, and the standard deviation represents an estimate of "noise" in flux observations. To calculate an appropriate uncertainty for every half-hour observation, the zero flux measurements were grouped into bins of equal numbers based on the magnitude of true covariance, and the standard deviation of that group is used as an estimate of the uncertainty. Due to signal dampening in the sensor lines and wind speed or direction, the true timing of the minimum covariance may change, and signal "leakage" may occur causing this calculation to be an overestimate of the uncertainty.

A second approach was tested during during the HFWR campaign, where $30 \mathrm{~min}$ of signal with just zero air from 


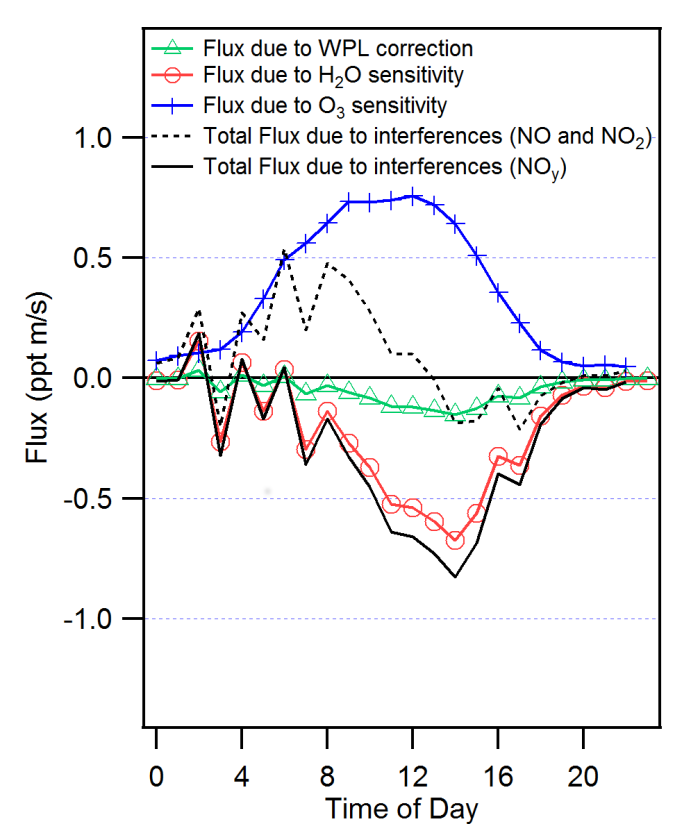

Fig. 3. Estimated flux interference terms due to water (WPL and chemiluminescent sensitivity) and ozone as a function of time of day.

near the end of the campaign was used to calculate covariances at every half hour with the measured vertical wind. This method, described in Billesbach (2011), and also applied to nitrogen oxide fluxes by Farmer and Cohen (2008), has been referred to as a "minimum detectable fluxes" approach. The zero flux observations were again grouped into bins based on the magnitude of the calculated true covariance from ambient air. While this approach avoids the signal leakage issue, its limitation is the assumption that uncertainties are independent of mixing ratio observations. We therefore expect uncertainties calculated by this method to be an underestimate.

The results of the uncertainty analysis are shown in Fig. 4 for $\mathrm{NO}_{\mathrm{y}}$ covariance and using the artificial lag of $60 \mathrm{~s}$. The average of the covariance using the artificial lag was $-0.01 \pm 1.67 \mathrm{ppt} \mathrm{m} \mathrm{s}^{-1}$ at HFWR, and $0.11 \pm 2.75 \mathrm{pptm} \mathrm{s}^{-1}$ at PROPHET, suggesting indeed that the error calculated with this approach is random. The absolute precision of the observations is directly related to the magnitude of the true covariance. So, maximum covariances around $-1 \mathrm{pptm} \mathrm{s}^{-1}$ have an uncertainty of $0.5 \mathrm{pptms}^{-1}$, while maximum covariances around $-30 \mathrm{ppt} \mathrm{m} \mathrm{s}^{-1}$ have an uncertainty of about $5 \mathrm{pptm} \mathrm{s}^{-1}$ (the observations are assigned a value based on $\pm 1 \sigma)$ at both PROPHET and HFWR. Here, observations are considered above the "detection limit" when they are greater than three times the uncertainty (i.e. $3 \sigma$ ). At PROPHET and HFWR, this is true of observations of deposition greater than about $3 \mathrm{pptms}^{-1}$. Observations of emissions during both campaigns all had a $3 \sigma$ uncertainty around $100 \%$. A similar analysis for the $\mathrm{NO}$ and $\mathrm{NO}_{2}$ fluxes showed that down- ward fluxes of NO greater than $1 \mathrm{pptms}^{-1}$ were above the detection limit, but all observed upward fluxes of $\mathrm{NO}$ and all observed $\mathrm{NO}_{2}$ fluxes were below the detection limit. Consistent results were found using the lag time of $20 \mathrm{~s}$.

We note that the results of this error analysis show a strongly linear relationship between estimated error and measured covariance. Using the intercept and slope from ordinary best-fit lines of this data would suggest that an alternative formulation of the $1 \sigma$ error could be expressed as $0.4 \mathrm{pptm} \mathrm{s}^{-1} \pm 16 \%$ and $0.4 \mathrm{pptm} \mathrm{s}^{-1} \pm 11 \%$ for the downward and upward fluxes at HFWR respectively, and $0.8 \mathrm{pptm} \mathrm{s}^{-1} \pm 13 \%$ and $0.3 \mathrm{ppt} \mathrm{m} \mathrm{s}^{-1} \pm 31 \%$ for downward and upward fluxes at PROPHET respectively.

Applying the zero air approach at HFWR yields slightly different results (shown in Fig. 4). As expected, the absolute precision is less a function of the true covariance. This method calculates a worse precision than the timelag approach for the lowest observations $\left( \pm 0.6 \mathrm{pptms}^{-1}\right.$ for covariances close to zero) and better precision at the highest observations $\left( \pm 1 \mathrm{pptm} \mathrm{s}^{-1}\right.$ for observations around $30 \mathrm{pptms}^{-1}$ ). The true uncertainty in the observations is likely somewhere in between these estimates.

\subsubsection{Cospectral analysis}

Cospectral analysis is often performed to investigate attenuation of high-frequency components of measured fluxes. In our case, the most significant sources of high-frequency attenuation are expected to be sampling frequency limitations (governed by flow rate) and attenuation of high-frequency variations in the tubing (governed by transit time and flow characteristics). Attenuation due to sensor separation between the inlet and sonic anemometer is assumed to be corrected for by the lag-time correction.

Attenuation due to tubing effects has been proposed to be accounted for by modelling a transfer function, $T_{t}(n)$, according to Eq. (1) in Suyker and Verma (1993), which would be applied to an ideal cospectrum:

$T_{t}(n)=\exp \left[-4 \pi^{2} n^{2} \Lambda L a u_{\mathrm{t}}^{-2}\right]$,

where $n$ is frequency $(\mathrm{Hz}), \Lambda$ is a tube-attenuation coefficient, $L$ is the tube length $(40 \mathrm{~m}), a$ is the tube radius, and $u_{\mathrm{t}}$ is the mean flow velocity in the tube. The form of the tubeattenuation coefficient depends on whether tube flow is turbulent or laminar. An estimate of the Reynolds number for flow in the instrument suggests flow is laminar, so that the tube-attenuation coefficient is governed by Eq. (3) in Suyker and Verma (1993), after Massman (1991):

$\Lambda=0.0104 v \operatorname{Re} D^{-1}$,

where $v$ is the kinematic viscosity of air, $R e$ is the Reynolds number, and $D$ is the molecular diffusivity of the gas (here using NO). For the purposes of this calculation, it was assumed that pressure in the tubing decreased linearly from 

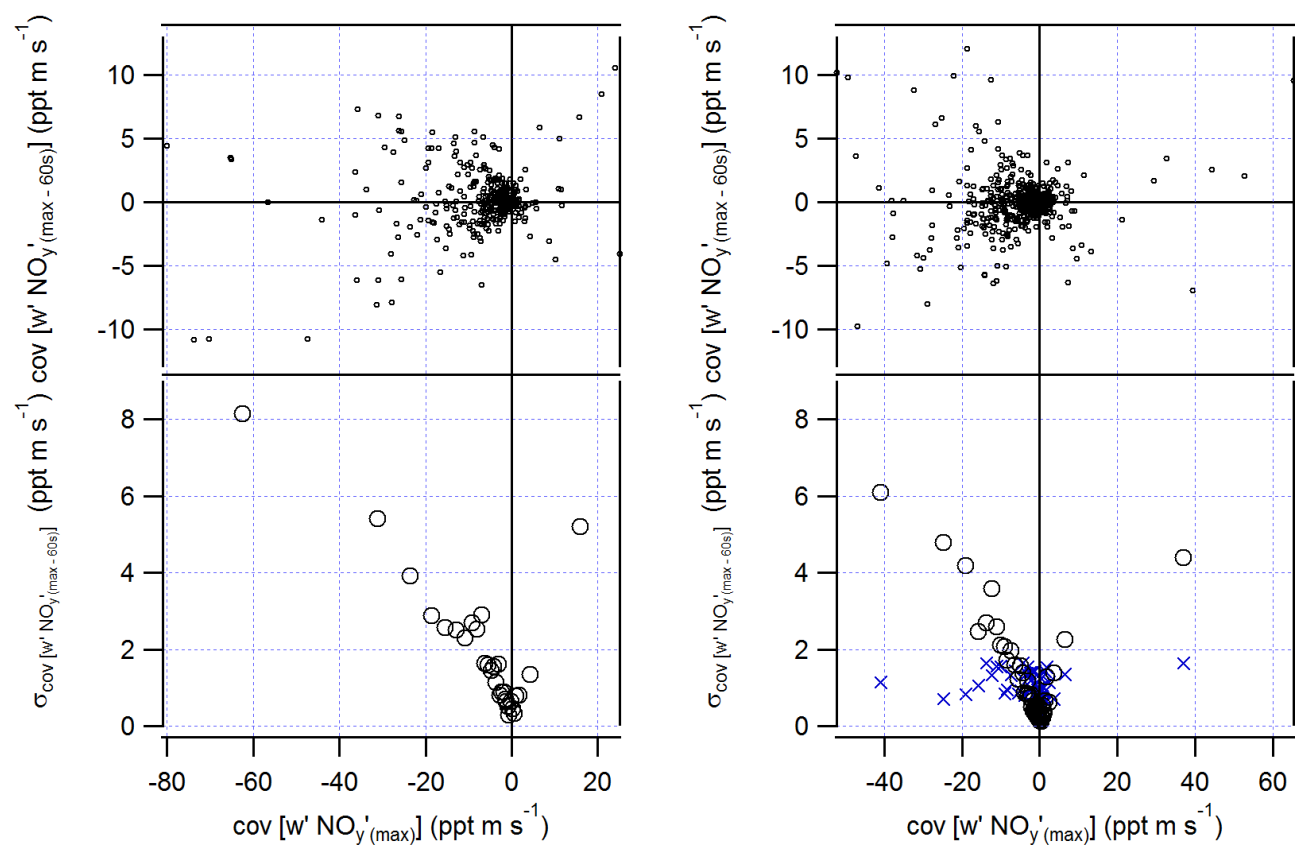

Fig. 4. Uncertainty calculated for half-hour measurements of $w^{\prime} \mathrm{NO}_{\mathrm{y}}{ }^{\prime}$. Top panels show the measured "zero" covariance by lagging the sensor wave by $60 \mathrm{~s}$, highlighting that these observations are grouped around the zero line. The bottom panels show the standard deviation of equally sized bins of zero measurements as a function of "true" covariance at maximum covariance lag time. Results for PROPHET are shown in (a), and results from HFWR are shown in (b), where the " $\mathrm{X}$ " markers are the results from the zero air approach.

ambient conditions at inlet to the total 11 torr at the reaction chambers.

For an ideal cospectrum, we use the $w^{\prime} T_{\mathrm{s}}^{\prime}$ cospectrum, where $T_{\mathrm{s}}^{\prime}$ is the temperature measured by the sonic anemometer. If modelled correctly, the attenuated cospectrum should agree with the observed $w^{\prime} \mathrm{NO}_{\mathrm{y}}^{\prime}$ cospectral shape.

To investigate this, Fig. 5 shows average normalized cospectra of $w^{\prime} \mathrm{NO}_{\mathrm{y}}^{\prime}$ from 31 July to 6 August for HFWR, and from 27 July to 2 August for PROPHET. These cospectra were calculated separately for stable conditions $(\mathrm{z} / \mathrm{L}>0.05)$ and unstable conditions $(z / L<-0.05)$, and only for similar mean wind conditions $\left(1-3 \mathrm{~m} \mathrm{~s}^{-1}\right)$, plotted based on the normalized frequency $(n=f z / u)$. The HFWR plots are based on $N=92$ and $N=50$ half-hour periods for the stable and unstable conditions, while the PROPHET plots are based on $N=84$ and $N=34$ half-hour periods for stable and unstable conditions respectively. Displayed on the top right panel is the dampening coefficient we expect in the $w^{\prime} \mathrm{NO}_{\mathrm{y}}^{\prime}$ cospectrum based on the transfer function calculated by Eq. (3) (and generally consistent with our understanding of instrument time response).

In all cases, the slopes of the cospectra of $w^{\prime} \mathrm{NO}_{\mathrm{y}}^{\prime}$ from the peak maximum to a normalized frequency of approximately 4 compare well with the slopes of the $w^{\prime} T_{\mathrm{s}}^{\prime}$ ("ideal") cospectra. In the case of HFWR, the unstable conditions show a pronounced increase in cospectral power beyond this frequency, when we expected a dampening according to tube attenua- tion, followed by a sharp decrease. For stable conditions, an increase is also observed at higher frequencies although it is not as dramatic. This behaviour could be expected in instruments with a large amount of noise in the high frequency. If noise is truly random, there should not be significant covariance with fluctuations in vertical wind; however this has been observed in other situations (e.g. methane fluxes reported in Querino et al. (2011) and Smeets et al. (2009)). In the case of PROPHET, we see a less marked increase in cospectral power at the high frequencies, indicating that perhaps noise was less of an issue during this campaign. However, we still note the absence of the expected decrease in cospectral power that would result from the signal dampening compared to the ideal cospectrum. In all four panels, we plot a straight dashed line at the normalized frequency of 4.5. Given the mean wind conditions for the half-hour periods that were averaged to make these plots $\left(2 \pm 0.5 \mathrm{~m} \mathrm{~s}^{-1}\right)$, this corresponds to a natural frequency of $0.3 \mathrm{~Hz}$.

Given the evidence in Fig. 5 that the spectral shapes close to the maximum cospectral power are similar for $w^{\prime} \mathrm{NO}_{\mathrm{y}}^{\prime}$ and $w^{\prime} T_{\mathrm{s}}^{\prime}$, and that it appears the tube-attenuation transfer function will not correctly account for cospectral issues at the higher frequencies, we apply a correction based on cospectral similarity instead of using the tube-attenuation transfer function. This correction is applied by comparing the integrated area under the non-normalized cospectra of $w^{\prime} \mathrm{NO}_{\mathrm{y}}^{\prime}$ up to $0.3 \mathrm{~Hz}$ with the ratio of the total covariance of $w^{\prime} T_{\mathrm{s}}^{\prime}$ to the integrated area under the non-normalized cospectra of 


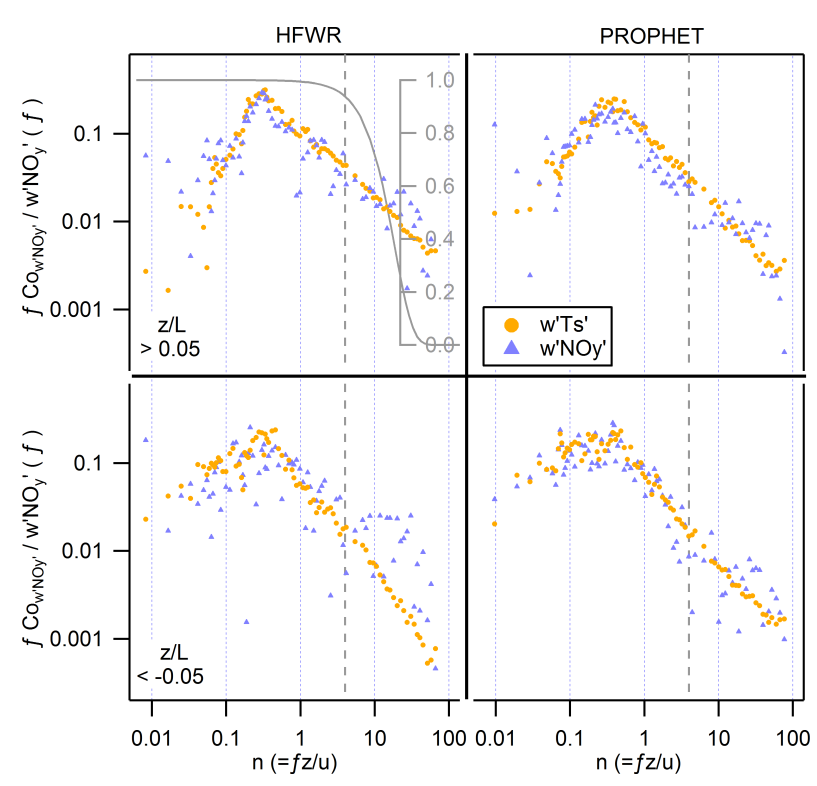

Fig. 5. Normalized cospectra of $w^{\prime} \mathrm{NO}_{\mathrm{y}}{ }^{\prime}$ for HFWR and PROPHET (left and right panels respectively) separated into stable and unstable conditions (top and bottom panels respectively). The solid grey line in the top left panel represented the tube-attenuation coefficient as calculated by Eq. 3. See text for further details.

$w^{\prime} T_{\mathrm{s}}^{\prime}$ up to $0.3 \mathrm{~Hz}$ :

$w^{\prime} \mathrm{NO}_{y, \text { ideal }}^{\prime}=\int_{0}^{0.3 \mathrm{~Hz}} \mathrm{Co}_{w^{\prime} \mathrm{NO}_{\mathrm{y}^{\prime}}} \frac{w^{\prime} T_{\mathrm{s} \text {,meas }}^{\prime}}{\int_{0}^{0.3 \mathrm{~Hz}} \mathrm{Co}_{w^{\prime} T_{\mathrm{s}}}{ }^{\prime}}$,

where $w^{\prime} \mathrm{NO}_{\mathrm{y} \text {,ideal }}^{\prime}$ is the corrected covariance for flux calculations. On average, the integrated area from 0 to $0.3 \mathrm{~Hz}$ of $\operatorname{Co}\left(w^{\prime} T_{\mathrm{s}}^{\prime}\right)$ was greater than $95 \%$ of the total area during the middle of the afternoon, and slightly higher than $90 \%$ of the total area around midnight.

\section{Observations}

\subsection{Mixing ratios of $\mathrm{NO}_{\mathrm{x}}, \mathrm{NO}_{\mathrm{y}}$, and $\mathrm{O}_{3}$}

The campaign average mixing ratios of $\mathrm{NO}, \mathrm{NO}_{2}$, and $\mathrm{NO}_{\mathrm{y}}$ are shown as a function of time of day in Fig. 6. NO and $\mathrm{NO}_{2}$ mixing ratios at PROPHET and HFWR displayed the expected diurnal patterns driven by photochemistry. Nighttime $\mathrm{NO}$ mixing ratios were close to zero, while $\mathrm{NO}_{2}$ built up to a median of around $500 \mathrm{ppt}$ at both PROPHET and HFWR. At PROPHET, $\mathrm{NO}_{2}$ levels continued to rise during the early morning hours to a median of close to $1000 \mathrm{ppt}$. This latter observation has been seen previously at PROPHET and has been discussed elsewhere (Alaghmand et al., 2011; Seok et al., 2013). During the later morning hours, photolysis of $\mathrm{NO}_{2}$ at both locations resulted in an increase in NO mixing ratios until an approximately steady state is reached in the afternoon. Midday $\mathrm{NO}$ and $\mathrm{NO}_{2}$ mixing ratios were 60 and $250 \mathrm{ppt}$ for PROPHET and 150 and $360 \mathrm{ppt}$ at HFWR respectively. Average $\mathrm{NO}_{\mathrm{y}}$ appears to exhibit different diurnal patterns at each location. During PROPHET, $\mathrm{NO}_{\mathrm{y}}$ levels peak in the early morning (median of $1600 \mathrm{ppt}$ ), then are steady throughout the afternoon and nighttime (median around $1000 \mathrm{ppt}$ ). At HFWR, median $\mathrm{NO}_{\mathrm{y}}$ reaches a maximum (approaching $1500 \mathrm{ppt}$ ) in the late morning that persists throughout the afternoon, until the evening when levels stabilize around $1000 \mathrm{ppt}$ for the rest of the night. Ozone mixing ratios at both locations rapidly decreased during the night, to a minimum around 07:00-07:30 LT of 21 and $23 \mathrm{ppb}$ at PROPHET and HFWR respectively, and increased during the day to a maximum around 16:00 LT of $32 \mathrm{ppb}$ on average.

\section{2 $\mathrm{NO}_{\mathrm{y}}$ fluxes}

$\mathrm{NO}_{\mathrm{y}}$ flux observations at both PROPHET $(N=348)$ and HFWR $(N=829)$ were predominantly of deposition, while the random uncertainty of upward fluxes that were observed was often greater than $100 \%$ (i.e., error may account for the majority of these instances). Deposition was higher at PROPHET than at HFWR, both in terms of maximum observed values and in terms of long-term average. At HFWR, $73.6 \%$ of the observed fluxes were negative (mean $\pm 1 \sigma=$ $-3.1 \pm 8.5 \mathrm{pptm} \mathrm{s}^{-1}$ ). At PROPHET, $81.9 \%$ of the observed fluxes were negative (mean $\pm 1 \sigma=-7.4 \pm 13.3 \mathrm{ppt} \mathrm{m} \mathrm{s}^{-1}$ ). Ten-day segments of the half-hour $\mathrm{NO}_{\mathrm{y}}$ flux time series from PROPHET and HFWR are shown in Fig. 7, with the corresponding half-hour average $\mathrm{NO}_{\mathrm{x}}$ and $\mathrm{NO}_{\mathrm{y}}$ mixing ratios. In general, fluxes scaled with $\mathrm{NO}_{\mathrm{y}}$ mixing ratios, with higher deposition measured at higher mixing ratios. The scaling of deposition with mixing ratio means that infrequent periods of high $\mathrm{NO}_{\mathrm{y}}$ mixing ratios can contribute disproportionately to long-term deposition (similar to the episodic nature of wet deposition). Episodes of high concentrations were usually associated with flow from particular regions (the contribution of polluted flow from upwind source areas is investigated in more detail below).

A particularly unusual event occurred at HFWR from 7 to 9 October 2011 during which very high $\mathrm{NO}_{\mathrm{y}}$ mixing ratios $(>18,>6$, and $>5 \mathrm{ppb}$ on 7,8 , and 9 of October respectively) were observed along with high $\mathrm{O}_{3}$ mixing ratios (above $60 \mathrm{ppb}$ on each day). Air quality monitoring data from across the region (http://www.airqualityontario.com) suggest this was an event characterized by high $\mathrm{O}_{3}$ and $\mathrm{PM}_{2.5}$ probably experienced by a large portion of central Ontario, extending at least as far as $140 \mathrm{~km}$ to the northwest of HFWR, and possibly as far as the Toronto area $200 \mathrm{~km}$ to the south. Data from the National Geophysical Data Center show the timing of this event coincided with large smoke plumes that were observed over north-central Ontario and northern Quebec for several days (http://maps.ngdc.noaa.gov/viewers/ firedetects). In light of the high $\mathrm{PM}_{2.5}$ that was recorded at an air quality monitoring site $20 \mathrm{~km}$ west of the HFWR tower 
Table 1. Average daily summertime $\mathrm{NO}_{\mathrm{y}}$ fluxes $\left(\mathrm{mg}(\mathrm{N}) \mathrm{m}^{-2}\right.$ day $\left.{ }^{-1}\right)$ above several North American forests measured directly by eddy covariance.

\begin{tabular}{cclc}
\hline Location & Coordinates & Time period & Average daily flux \\
\hline Schefferville $^{\mathrm{a}}$ & $54^{\circ} 50^{\prime} \mathrm{N}, 66^{\circ} 40^{\prime} \mathrm{W}$ & Jul-Aug 1990 & -0.11 \\
HFWR $^{\mathrm{b}}$ & $45^{\circ} 17^{\prime} \mathrm{N}, 78^{\circ} 32^{\prime} \mathrm{W}$ & 27 Jul-6 Oct 2011 & -0.14 \\
PROPHET $^{\mathrm{c}}$ & $45^{\circ} 33^{\prime} \mathrm{N}, 84^{\circ} 42^{\prime} \mathrm{W}$ & Aug 2005 & -0.15 \\
PROPHET $^{\mathrm{b}}$ & $45^{\circ} 33^{\prime} \mathrm{N}, 84^{\circ} 42^{\prime} \mathrm{W}$ & 24 Jul-14 Aug 2012 & -0.34 \\
Harvard Forest $^{\mathrm{a}}$ & $42^{\circ} 32^{\prime} \mathrm{N}, 72^{\circ} 11^{\prime} \mathrm{W}$ & 1990-1996 & -0.70 \\
Duke Forest $^{\mathrm{d}}$ & $35^{\circ} 58^{\prime} \mathrm{N}, 79^{\circ} 05^{\prime} \mathrm{W}$ & $11-25 \mathrm{Jul} 2003$ & -0.75 \\
\hline
\end{tabular}

a Munger et al. (1998)

${ }^{\mathrm{b}}$ Present study.

${ }^{c}$ Hogg (2007).

${ }^{\mathrm{d}}$ Sparks et al. (2008).
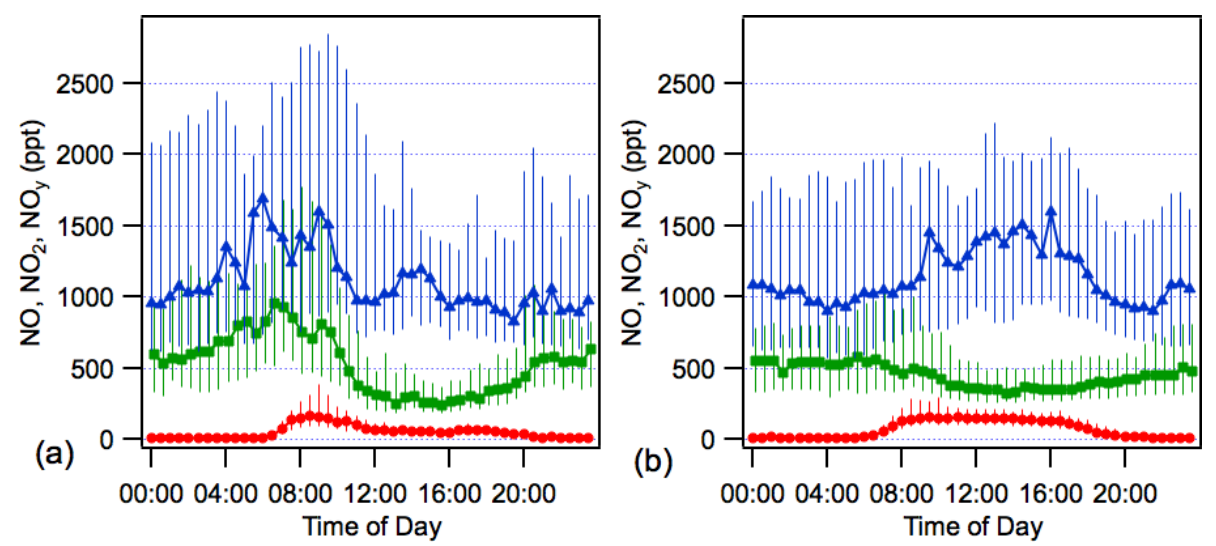

Fig. 6. Diurnal average $\mathrm{NO}$ (red circles), $\mathrm{NO}_{2}$ (green squares), and $\mathrm{NO}_{\mathrm{y}}$ (blue triangles) mixing ratios at (a) PROPHET and (B) HFWR. Lines with markers indicate the median, and vertical lines denote the middle $50 \%$ distribution of the data.

(hourly average concentrations greater than $20 \mu \mathrm{g} \mathrm{m}{ }^{-3}$, when they were typically less than $6 \mu \mathrm{g} \mathrm{m}^{-3}$ in the preceding and following weeks), we take this as evidence that the source of the high concentrations could have been forest fire. The $\mathrm{NO}_{\mathrm{y}}$ fluxes during this time displayed a clearly different pattern compared to the rest of the campaign as illustrated in Fig. 8. High downward fluxes were recorded during the night, and high upward fluxes were recorded during the day. During this period, very steep changes in the atmospheric concentrations are observed. Under such conditions. it is unlikely that the storage term can be ignored in calculating the flux, making the eddy covariance observations alone unrepresentative of true flux. In the absence of vertical profile observations, the storage term can be estimated to a first order by the equation

$F_{S}=\frac{d C}{d t} h$.

For example, the decrease in $\mathrm{NO}_{\mathrm{y}}$ concentrations from 07:30 to 11:00 on the morning of 7 October leads to an average storage flux term of around $-30 \mathrm{pptm} \mathrm{s}^{-1}$. This term is roughly equal to the positive eddy covariance flux measured. The interpretation of the flux measurements during this time is therefore problematic without measurements of $\mathrm{NO}_{\mathrm{y}}$ at mul- tiple heights to accurately determine the storage term. For this reason, the $\mathrm{NO}_{\mathrm{y}}$ flux observations during this time are excluded from the discussion of the rest of the campaign that follows.

$\mathrm{NO}_{\mathrm{y}}$ fluxes as a function of time of day from PROPHET and HFWR are shown in Fig. 9. Hourly averages are also plotted (observations were grouped into hourly bins instead of half-hour bins to increase the number of data points), and the diurnal traces of $u_{*}$ and stability parameter $z \mathrm{~L}^{-1}$ are also shown in Fig. 9. Fluxes at both sites exhibited diurnal patterns, with higher deposition during the daytime and fluxes close to zero at nighttime. Occasionally, net emission fluxes were observed in the afternoons, and there were several examples of high deposition throughout the night during both campaigns. Deposition peaked at PROPHET between 11:00 and 16:00 LT, exceeding $15 \mathrm{ppt} \mathrm{m} \mathrm{s}^{-1}$ on average. Previous $\mathrm{NO}_{\mathrm{y}}$ flux measurements from PROPHET using a similar method during August 2005 report a lower peak in average daytime deposition of around $10 \mathrm{ppt} \mathrm{m} \mathrm{s}^{-1}$ (Hogg, 2007), although occurring at a similar time of day. Deposition at HFWR peaked earlier in the day and at about half the magnitude compared to PROPHET (about $7 \mathrm{ppt} \mathrm{ms}^{-1}$ ). While 

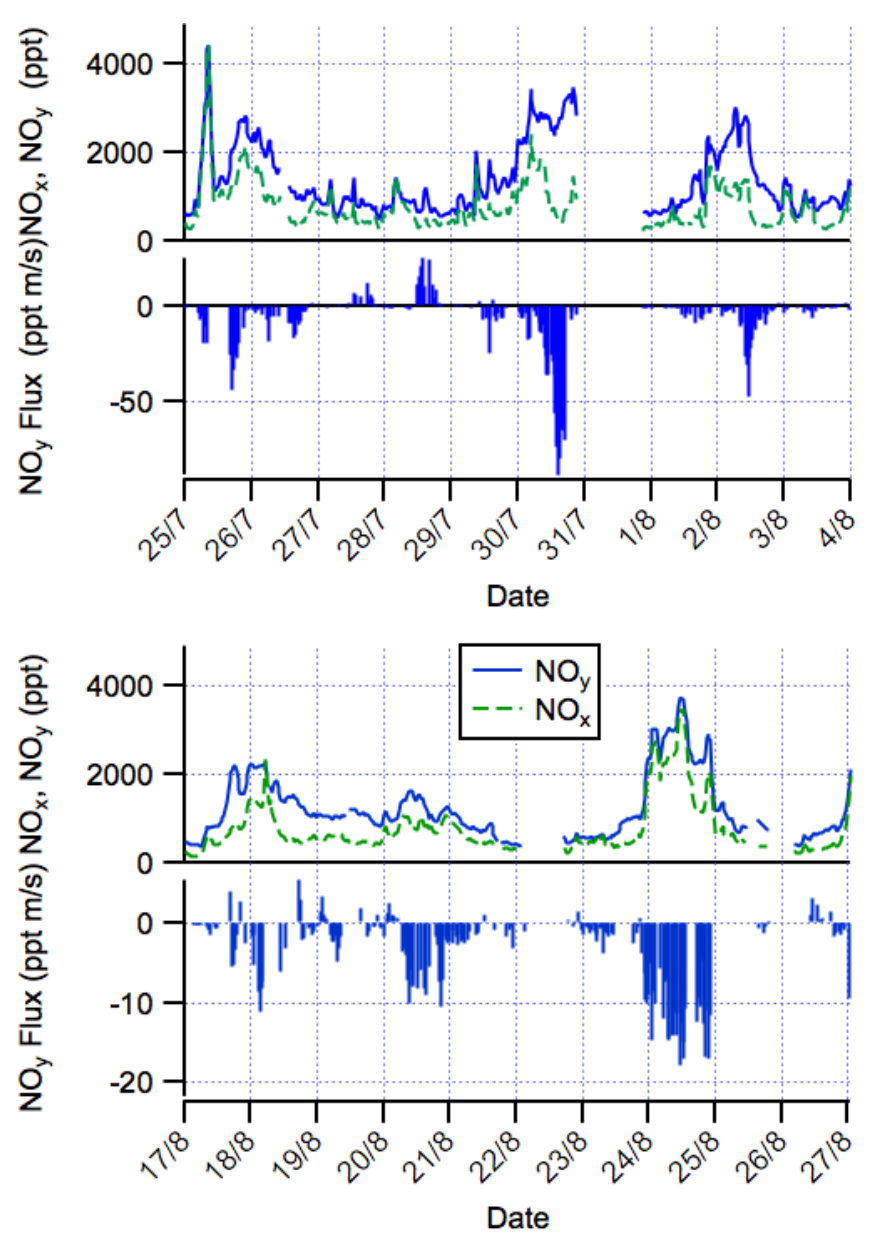

Fig. 7. Example 10 day time series for $\mathrm{NO}_{\mathrm{x}}$ and $\mathrm{NO}_{\mathrm{y}}$ mixing ratios and eddy covariance $\mathrm{NO}_{\mathrm{y}}$ fluxes at (a) PROPHET and (b) HFW.

average deposition at PROPHET seems to follow the pattern in $u_{*}$, deposition at HFWR peaks earlier than the maximum $u_{*}$.

$\mathrm{NO}_{\mathrm{y}}$ fluxes roughly correlated with $\mathrm{NO}_{\mathrm{y}}$ mixing ratios. Deposition velocities $\left(v_{\text {dep }}\right)$ are calculated as the observed flux divided by observed mixing ratio, and are generally reported in units of $\mathrm{cm} \mathrm{s}^{-1}$. Here, the convention is used that positive deposition velocities correspond to deposition (negative flux). Note that this observed quantity is actually the net result of both upward and downward fluxes, and is therefore also known alternatively as the "exchange velocity". At any given time this parameter is expected to be controlled by atmospheric conditions and, for example, the ratio of $\mathrm{NO}_{\mathrm{x}}$ to $\mathrm{NO}_{\mathrm{y}}$. As expected, $v_{\text {dep }}$ exhibited a diurnal pattern, with higher values during the day (corresponding to more turbulent atmospheric conditions) and lower values at night (corresponding to more stable conditions generally); however they were highly variable. Average midday (12:00-16:00) values of $v_{\text {dep }}$ at HFWR and PROPHET were $0.20 \pm 0.25$ and $0.67 \pm 1.24 \mathrm{~cm} \mathrm{~s}^{-1}$ respectively. Aver- age nighttime (00:00-04:00) values of $v_{\text {dep }}$ were $0.09 \pm 0.23$ and $0.08 \pm 0.16 \mathrm{~cm} \mathrm{~s}^{-1}$ respectively.

Since the $\mathrm{NO}_{\mathrm{y}}$ flux observations at both locations were discontinuous, gap-filling such a short data set is not feasible. Net daily $\mathrm{NO}_{\mathrm{y}}$ exchange at PROPHET and HFWR during the campaign was therefore estimated by integrating the mean diurnal traces. At PROPHET, net deposition of $0.34 \mathrm{mg}(\mathrm{N}) \mathrm{m}^{-2}$ day $^{-1}$ was calculated. At HFWR, the average for the campaign (Fig. 9) calculates a net daily deposition of $0.14 \mathrm{mg}(\mathrm{N}) \mathrm{m}^{-2} \mathrm{day}^{-1}$. These are of the same order of magnitude as the handful of previously reported summertime $\mathrm{NO}_{\mathrm{y}}$ fluxes from other forest sites across North America (Sparks et al., 2008; Munger et al., 1998; Hogg, 2007). Table 1 compares mean results from previous $\mathrm{NO}_{\mathrm{y}}$ eddy covariance flux studies in $\mathrm{mg}(\mathrm{N}) \mathrm{m}^{-2} \mathrm{day}^{-1}$, with a focus on summertime observations. Results from the present PROPHET campaign lie between previously observed values, while results from HFWR are on the low end. The sites are listed in order of ascending average daily flux, which also seems to generally follow the order of lowest to highest average $\mathrm{NO}_{\mathrm{y}}$ mixing ratios observed during each campaign. A detailed comparison of these results, however, is not straightforward due to the span of over two decades across the observations that have seen strong declines in $\mathrm{NO}_{\mathrm{x}}$ emissions in these regions of North America. Moreover, the short duration (a few weeks) of most of the campaigns may not accurately capture longer-term averages.

\section{3 $\mathrm{NO}_{\mathrm{x}}$ fluxes}

Eddy covariance $\mathrm{NO}$ and $\mathrm{NO}_{2}$ flux observations were made for several days at PROPHET, and for several weeks at HFWR (see Sect. 2.2). Uncertainties in individual half-hour $\mathrm{NO}$ and $\mathrm{NO}_{2}$ flux observations were around $100 \%$ most of the time, indicating that the precision of this instrument was not adequate to make reliable observations of $\mathrm{NO}_{\mathrm{x}}$ flux at these sites. We restrict our interpretation of this data to the resulting diurnal average profiles in order to at least reduce the effects of random variability by grouping observations from the same time of day.

The diurnal plots are shown in Fig. 10. Generally, mean nighttime observations were close to zero, while, during the daytime, mean fluxes outside the random variability could be detected. Upward fluxes of $\mathrm{NO}_{2}$ peaked at mid-morning (median of +4.8 and $+2.6 \mathrm{pptm} \mathrm{s}^{-1}$ at PROPHET and HFWR respectively) and downward fluxes of NO peaked at the same time (median of -4.0 and $-2.1 \mathrm{ppt} \mathrm{m} \mathrm{s}^{-1}$ at PROPHET and HFWR respectively). Daytime fluxes of $\mathrm{NO}$ and $\mathrm{NO}_{2}$ largely cancel each other out. Between 11:00 and 15:00, the average $\mathrm{NO}$ and $\mathrm{NO}_{2}$ fluxes were $-1.3 \pm 1.0$ and $+1.5 \pm$ $1.4 \mathrm{ppt} \mathrm{m} \mathrm{s}^{-1}$ at HFWR. At PROPHET, the average NO and $\mathrm{NO}_{2}$ fluxes between 11:00 and 15:00 were $-0.8 \pm 0.8$ and $1.5 \pm+1.0 \mathrm{pptm} \mathrm{s}^{-1}$. Therefore, on average, these fluxes appeared to be statistically indistinguishable from being equal and opposite. 

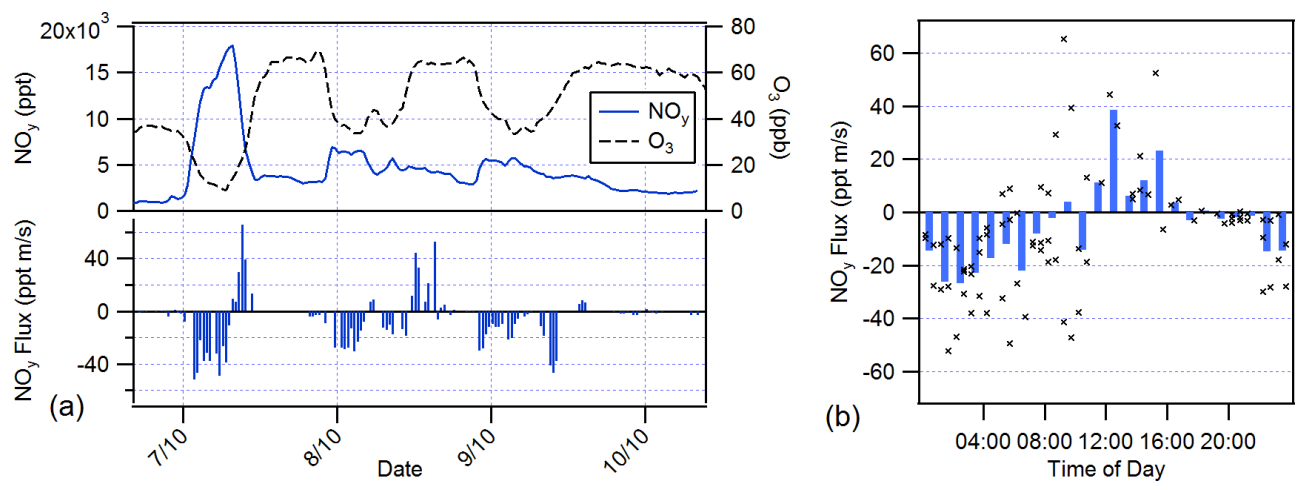

Fig. 8. (a) Mixing ratio and flux observations, and (b) diurnal average during the high-pollution event from 7 to 9 October 2011 at HFWR.
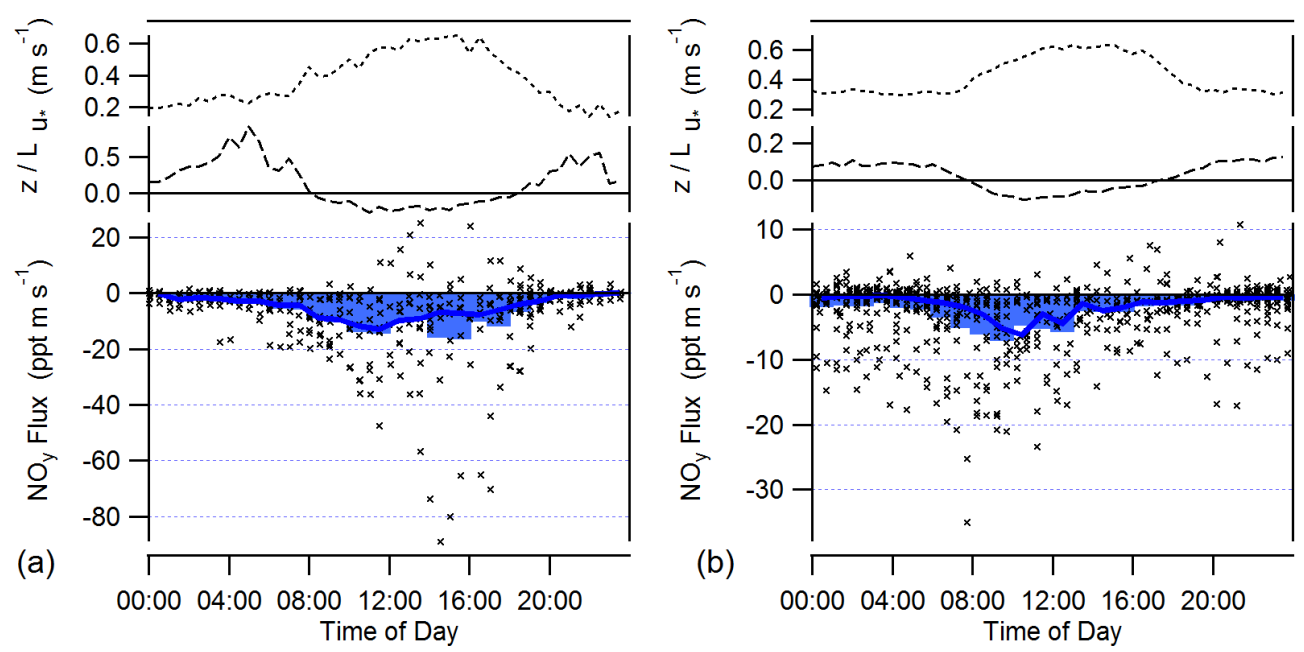

Fig. 9. Diurnal median $u_{*}, \mathrm{MO} \mathrm{z} \mathrm{L}^{-1}$, and eddy covariance $\mathrm{NO}_{\mathrm{y}}$ fluxes for (a) PROPHET and (b) HFWR. In the lower panel, bars represent the hourly mean, the solid line represents the median, and the markers represent individual observations.

\section{Discussion}

\subsection{Influence of transport}

As a basic measure of the influence of transport, we grouped $\mathrm{NO}_{\mathrm{y}}$ flux observations by wind direction ("north", "southwest", and "southeast") at both locations. At HFWR, the north category only included observations from 270 to $360^{\circ}$, due to the influence of the tower from 0 to $93^{\circ}$. At PROPHET, north included all observations between 270 and $90^{\circ}$. The results are shown in Fig. 11, and other quantities as a function of wind direction are summarized in Table 2 . The data from both locations reveal a strong influence of wind direction on the magnitude of deposition.

At PROPHET, flow from the southwest (from the direction of the Milwaukee and Chicago areas across Lake Michigan) is associated with the highest deposition. Observations from this direction were also associated with the highest $\mathrm{NO}_{\mathrm{y}}$ mixing ratios, and the highest $v_{\text {dep }}$. Deposition is also enhanced when flow from the southeast (from the direction of Detroit, Cleveland, and populated regions in southwest- ern Ontario) is observed, but the calculated $v_{\text {dep }}$ was not as high. This may be a result of the higher $\mathrm{NO}_{\mathrm{x}} / \mathrm{NO}_{\mathrm{y}}$ ratios that were observed coming from this direction. Observations from the north are still of deposition on average, although with less skew towards high values. $\mathrm{NO}_{\mathrm{x}}$ and $\mathrm{NO}_{\mathrm{y}}$ mixing ratios were lowest coming from this direction. Despite a similar $\mathrm{NO}_{\mathrm{x}} / \mathrm{NO}_{\mathrm{y}}$ mixing ratio to that coming from the southwest, the $v_{\text {dep }}$ is much lower (in fact, the lowest). Investigation of this data showed that flow from the north was associated with the most (and highest) observations of $\mathrm{NO}_{\mathrm{y}}$ emission, which will counteract deposition and complicate the interpretation of $v_{\text {dep }}$.

At HFWR, deposition looks approximately normally distributed around zero when flow is coming from the north, whereas deposition is enhanced when wind comes from the south (the direction of the greater Toronto area in southern Ontario) and skewed towards high values. Observations from the southwest and southeast have similarly high $\mathrm{NO}_{\mathrm{x}}$ and $\mathrm{NO}_{\mathrm{y}}$ mixing ratios, and comparable $v_{\text {dep }}$. When air is coming from the north, deposition velocities were found to 

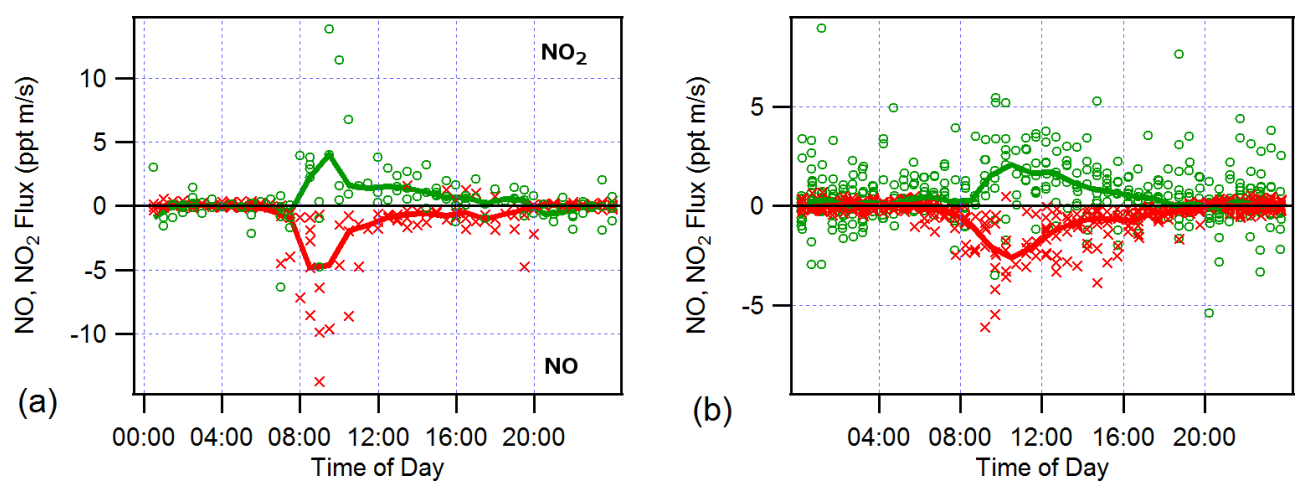

Fig. 10. Diurnal plot of $\mathrm{NO}$ (red crosses) and $\mathrm{NO}_{2}$ (green open circles) fluxes observed at (a) PROPHET and (b) HFWR. Solid lines indicate hourly median.

Table 2. Median observed quantities as a function of wind direction. $\mathrm{NO}_{\mathrm{x}}$ and $\mathrm{NO}_{\mathrm{y}}$ mixing ratios in ppt, fluxes in pptms $\mathrm{s}^{-1}$, and $v_{\mathrm{dep}}$ in $\mathrm{cms}^{-1}$.

\begin{tabular}{ccccccc}
\hline \multicolumn{1}{c}{ PROPHET } & & $\mathrm{NO}_{\mathrm{x}}$ & $\mathrm{NO}_{\mathrm{y}}$ & $\mathrm{NO}_{\mathrm{x}} / \mathrm{NO}_{\mathrm{y}}$ & $\mathrm{NO}_{\mathrm{y}}$ flux & $v_{\text {dep }}$ \\
\hline \multirow{4}{*}{ HFWR } & $\mathrm{N}$ & 420 & 815 & 0.51 & -1.6 & -0.17 \\
& $\mathrm{SE}$ & 1058 & 2440 & 0.52 & -7.1 & -0.42 \\
& $\mathrm{~N}$ & 390 & 1271 & 0.73 & -2.4 & -0.19 \\
\hline & $\mathrm{SW}$ & 633 & 769 & 0.57 & -0.2 & -0.02 \\
& $\mathrm{SE}$ & 554 & 939 & 0.61 & -1.3 & -0.14 \\
& & & & & -1.4 & -0.14 \\
\hline
\end{tabular}

be near zero. Like at PROPHET, these data were associated with more observations of emission. However, in this case it was also found that afternoon observations from this direction occurred rarely, so that this deposition velocity reflects nighttime conditions more heavily (such an issue was not observed for PROPHET). This selection bias does not seem to be a result of a diurnal pattern in wind direction, but rather is likely a result of spike removal due to observed generator effects.

The differences in $v_{\text {dep }}$ at HFWR and PROPHET, when comparing observations with similar $\mathrm{NO}_{\mathrm{x}} / \mathrm{NO}_{\mathrm{y}}$ mixing ratios (e.g. ratios of $0.5-0.6$ in Table 2), could be explained by several mechanisms: differences in canopy and understory structure; differences in $\mathrm{NO}_{\mathrm{z}}\left(=\mathrm{NO}_{\mathrm{y}}-\mathrm{NO}_{\mathrm{x}}\right)$ composition; differences in $\mathrm{NO}_{\mathrm{y}}$ emission strengths; and differences in turbulence or mixing mechanisms.

PROPHET and HFWR represent receptor locations where the amount of pollution received is dependent on transport conditions and source regions. It is not surprising, therefore, that there is a clear association of deposition with wind direction; $\mathrm{NO}_{\mathrm{y}}$ deposition has already been seen to be driven by atmospheric mixing ratios. However, these observations represent some of the first directly measured evidence of this effect on the dry deposition of reactive nitrogen oxides at midlatitude forests in North America since the long-term Harvard Forest results from 15 years ago (Munger et al.,
1996), and may therefore be valuable for comparisons with model output. Despite strong reductions over the last decade in anthropogenic reactive nitrogen oxide sources, transport of $\mathrm{NO}_{\mathrm{y}}$ still contributes significantly to nitrogen deposition at these locations. Since the deposition in these regions can be very low or very high depending on meteorological conditions, they provide a good dynamic range for validation. In the future, more intensive campaigns at these locations with speciated measurements of $\mathrm{NO}_{\mathrm{y}}$ should elucidate how source region impacts the chemical components that are being deposited, providing further constraints on modelled deposition.

\subsection{Total deposition budget of reactive nitrogen oxides}

It is desirable to assess the contribution of wet and dry deposition to total reactive nitrogen oxide deposition. As described in the Introduction, usually these budgets rely heavily on models and are associated with sometimes unquantifiable uncertainties (Holland et al., 2005). While wet deposition is easily measured directly using precipitation sampling networks, dry deposition is estimated using deposition models with ambient concentrations as inputs. The contributions of wet versus dry deposition not only depends on meteorological considerations, but also on the proximity to sources.

Deposition budgets at individual sites where dry and wet deposition were both measured directly (instead of being 

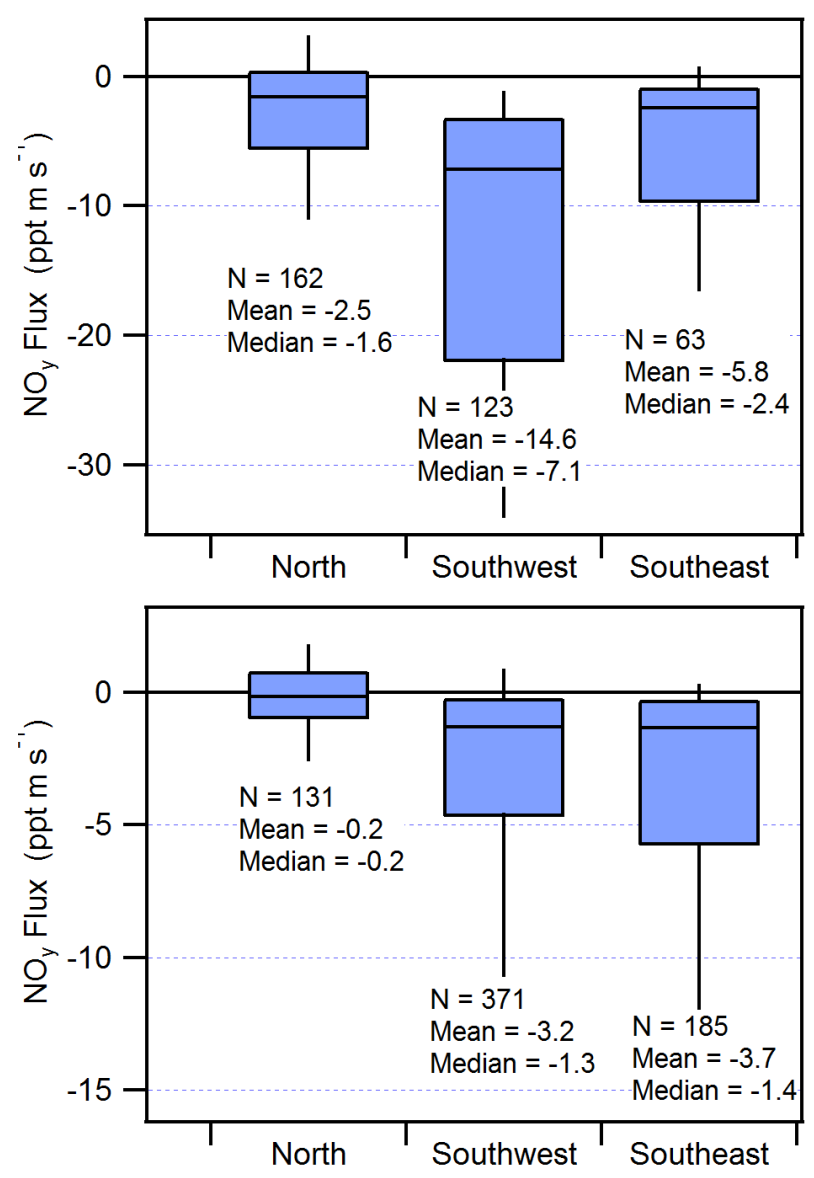

Fig. 11. Box-and-whisker plots of $\mathrm{NO}_{\mathrm{y}}$ flux observations (ppt ms ${ }^{-1}$ ), organized by observed wind direction at (a) PROPHET and (b) HFWR. Boxes represent the 25th to 75th percentiles, and whiskers are drawn to the 10th and 90th percentiles.

inferred) are rare, and even rarer when contributions from individual $\mathrm{NO}_{\mathrm{y}}$ species are measured simultaneously. Munger et al. (1998) describe the budget for Harvard Forest using $\mathrm{NO}_{\mathrm{y}}$ eddy covariance flux data collected from 1990 to 1996, and show that, on an annual basis, dry deposition contributes $34 \%$ of total $\mathrm{NO}_{\mathrm{y}}$ inputs; the same paper summarizes data collected during the summer of 1990 over a black spruce woodland in northern Quebec which show that contributions of dry deposition are roughly the same. Sparks et al. (2008) report a much higher dry $\mathrm{NO}_{\mathrm{y}}$ deposition contribution to total nitrate on an annual basis of around $60 \%$ above a North Carolina pine plantation. Other studies using eddy covariance have applied novel instruments to directly determine the contribution of individual species over short-term (several months or less) intensive field campaigns at a number of sites across North America (Horii et al., 2004; Turnipseed et al., 2006; Farmer and Cohen, 2008; Wolfe et al., 2009; Min et al., 2012; Zhang et al., 2012). Gradient methods above forest canopies have also been used to determine the contributions of certain species to $\mathrm{NO}_{\mathrm{y}}$ deposition or emission budgets (Sievering et al., 2001; Pryor et al., 2002; Neirynck et al., 2007; Wolff et al., 2010).

For the present analysis, wet deposition observations that were made over the concurrent summer months were scaled down to an average daily flux for comparison with the average daily $\mathrm{NO}_{\mathrm{y}}$ flux measured during the two campaigns.

\subsubsection{PROPHET}

The National Atmospheric Deposition Program includes a monitoring station at Douglas Lake, within the UMBS property where the PROPHET tower is also located. Here, the concentration of nitrate in precipitation is recorded, and can thus be used in a comparison with the dry deposition measured during the campaign. Data from July and August 2012 were accessed from http://nadp.sws. uiuc.edu/. Total nitrate deposited in precipitation from

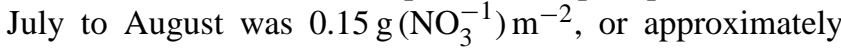
$0.55 \mathrm{mg}(\mathrm{N}) \mathrm{m}^{-2} \mathrm{day}^{-1}$ on average over July-August. The diurnally integrated average $\mathrm{NO}_{\mathrm{y}}$ flux observations provide an estimate of dry deposition of $0.34 \mathrm{mg}(\mathrm{N}) \mathrm{m}^{-2} \mathrm{day}^{-1}$. This would suggest that, during this summer period, dry deposition contributed just under $40 \%$ of the $\mathrm{N}$ in total reactive nitrogen oxide deposition.

This is significantly higher than the estimates made for August 2005, where $\mathrm{NO}_{\mathrm{y}}$ fluxes were measured by eddy covariance at PROPHET (Hogg, 2007). During that campaign, dry $\mathrm{NO}_{\mathrm{y}}$ deposition only contributed on the order of $10 \%$ of total $\mathrm{NO}_{\mathrm{y}}$ deposition (Hogg, 2007). Although these measurements were made at very similar times of the year, the 2005 and the present 2012 campaign estimates are only based on three weeks of dry deposition measurements each, and are therefore subject to significant short-term variations in pollutant concentrations and meteorology, which may explain some of the discrepancy. Both wet and dry deposition can be highly episodic, with short-term periods contributing disproportionately to total deposition. This underscores the need for fairly long-term measurements if better constraints are to be placed on the overall nitrogen deposition budget. However, both campaigns agree that $\mathrm{NO}_{\mathrm{x}}$ was not a significant component of net depositing $\mathrm{NO}_{\mathrm{y}}$.

\subsubsection{HFWR}

While precipitation was not monitored in the direct vicinity of the tower at HFWR, the Canadian Air and Precipitation Monitoring Network records nitrate in precipitation at three sites located in surrounding areas, with data available for 2011 (http://www.ec.gc.ca/rs-mn/). Here, total nitrate in precipitation from July to September was calculated. Here we consider Warsaw Caves $\left(44^{\circ} 27^{\prime} 36^{\prime \prime} \mathrm{N}\right.$, $78^{\circ} 7^{\prime} 48^{\prime \prime} \mathrm{W}$ ), located approximately $80 \mathrm{~km}$ south of HFWR, which had $0.24 \mathrm{~g}\left(\mathrm{NO}_{3}^{-1}\right) \mathrm{m}^{-2}$; Sprucedale $\left(45^{\circ} 25^{\prime} 12^{\prime \prime} \mathrm{N}\right.$, $79^{\circ} 29^{\prime} 24^{\prime \prime} \mathrm{W}$ ), located approximately $80 \mathrm{~km}$ northeast of HFWR, which had $0.17 \mathrm{~g}\left(\mathrm{NO}_{3}^{-1}\right) \mathrm{m}^{-2}$; and Chalk River 
$\left(65^{\circ} 3^{\prime} 36^{\prime \prime} \mathrm{N}, 77^{\circ} 24^{\prime} 36^{\prime \prime} \mathrm{W}\right)$, located approximately $110 \mathrm{~km}$

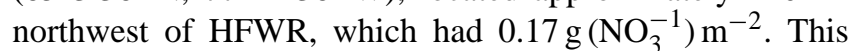
puts relatively good bounds on possible wet nitrate deposition at HFWR, located centrally in relation to these three sites. We will use an estimate of $0.2 \mathrm{~g}\left(\mathrm{NO}_{3}^{-1}\right) \mathrm{m}^{-2}$, which results in wet deposition average of around $0.50 \mathrm{mg}(\mathrm{N}) \mathrm{m}^{-2} \mathrm{day}^{-1}$ over that time. Wet deposition measurements at the HFWR tower were collected manually during the summer and fall of 2009, which also result in an estimate of wet nitrate contributions on the order of $0.59 \mathrm{mg}(\mathrm{N}) \mathrm{m}^{-2} \mathrm{day}^{-1}$ (De Sousa, 2010), agreeing well with the other observations at different sites in the vicinity from 2011.

The diurnally integrated average $\mathrm{NO}_{\mathrm{y}}$ flux observations give an estimated deposition flux of $0.14 \mathrm{mg}(\mathrm{N}) \mathrm{m}^{-2} \mathrm{day}^{-1}$. This suggests that, during this summer period, dry deposition contributed on the order of $22 \%$ of total $\mathrm{N}$ in reactive nitrogen oxide deposition for the HFWR region. The estimate of the contributions of dry and wet deposition at HFWR is in reasonable agreement with previous modelling results, where the dry deposition of $\mathrm{NO}_{\mathrm{y}}$ at eight locations across Canada contributed between 17 and $60 \%$ of the total reactive nitrogen oxide deposition (Zhang et al., 2009). At the two locations closest to HFWR, the contributions were 17 and $24 \%$ (modelled for Sprucedale and Chalk River respectively).

\subsection{Above-canopy $\mathrm{NO}$ and $\mathrm{NO}_{2}$ fluxes}

Above-canopy $\mathrm{NO}_{\mathrm{x}}$ fluxes by single-point eddy covariance are difficult to interpret due to the comparable chemical and turbulent timescales (e.g. see Gao et al., 1991). This is exacerbated in the present work by the flux interferences due to water vapour and $\mathrm{O}_{3}$, which have been estimated on average to approach $1 \mathrm{ppt} \mathrm{m} \mathrm{s}^{-1}$ (albeit in opposite directions) during the daytime (see Fig. 3).

When observed directly, the $\mathrm{NO}$ and $\mathrm{NO}_{2}$ fluxes showed that each tended to cancel the other out, suggesting $\mathrm{NO}_{\mathrm{x}}$ may not make an important contribution to $\mathrm{NO}_{\mathrm{y}}$ deposition at these forests. However, there were times during $\mathrm{NO}_{\mathrm{y}}$ flux sampling that indicate otherwise. For example, at HFWR during the night of 24 August (see Fig. 7), the $\mathrm{NO}_{\mathrm{x}} / \mathrm{NO}_{\mathrm{y}}$ ratios were high and large $\mathrm{NO}_{\mathrm{y}}$ downward flux was observed. $\mathrm{NO}_{2}$ mixing ratios at this time were around 2700 ppt. Assuming the deposition velocity of $\mathrm{NO}_{2}$ at this time could have been around $0.2 \mathrm{~cm} \mathrm{~s}^{-1}$ (Zhang et al., 2003), $\mathrm{NO}_{2}$ alone could have accounted for around $60 \%$ of the apparent deposition. If we assumed the difference between $\mathrm{NO}_{\mathrm{y}}$ and $\mathrm{NO}_{\mathrm{x}}$ was made up entire of nitric acid, which could have a deposition velocity close to $1.2 \mathrm{~cm} \mathrm{~s}^{-1}$ under the same conditions (Zhang et al., 2003), it would have approximately made up the rest of the apparent deposition.

The upward flux of $\mathrm{NO}_{2}$ and downward flux of NO observed at PROPHET and HFWR are likely an example of classic chemical flux divergence, where the true flux at the biosphere-atmosphere interface is not maintained at the mea- surement height (as has been predicted by models, e.g. (Gao et al., 1993), and observed elsewhere, e.g. (Horii et al., 2004)). This results from fast chemistry below the canopy which depletes above-soil NO concentrations (from emission) and produces $\mathrm{NO}_{2}$. Since the lifetime of $\mathrm{NO}_{2}$ below the canopy can be longer than above the canopy due to the extinction of incoming radiation, significant vertical gradients in the $\mathrm{NO} / \mathrm{NO}_{2}$ ratio may develop and result in this chemical flux divergence. The observations presented here of this flux-divergence above forest canopies are, as far as we know, some of only very few direct observations (see for example Horii et al., 2004). Given that we have confirmed this behaviour at these sites, future measurements that investigate flux divergence at HFWR and PROPHET would be beneficial since little experimental work is available on this topic.

Due to the flux-divergence problem we have no constraint on the true magnitudes of $\mathrm{NO}$ emission fluxes from the soil and $\mathrm{NO}_{2}$ deposition to the canopy. In addition to this problem, the detection of soil emissions by above-canopy flux observations also depends on the extent of canopy reduction processes and the relative importance of dry deposition to the canopy (since eddy covariance represents the net result of emission, deposition, and chemistry). Even the traditional assumption that $\mathrm{NO}_{\mathrm{x}}$ (as the sum of $\mathrm{NO}$ and $\mathrm{NO}_{2}$ ) is analogous to a conserved species, where the timescale of chemical conversion is much longer than turbulent timescales, is being challenged by evidence of within-canopy chemistry that may drive vertical chemical gradients (Min et al., 2013).

Typically, soil emissions are measured by chamber techniques directly above the soil surface. Such observations have informed attempts to parameterize soil $\mathrm{NO}_{\mathrm{x}}$ emissions globally as a function of ecosystem type, soil temperature and wetness, fertilizer application, and precipitation patterns (e.g. Yienger and Levy, 1996; Steinkamp, 2011; Hudman, 2012). We are aware of very few published observations of NO emissions from North American forest soils (and none were performed during the present campaigns). Williams et al. (1988) report mean soil NO emissions from a forest in Pennsylvania of $1.2 \mathrm{ng}(\mathrm{N}) \mathrm{m}^{-2} \mathrm{~s}^{-1}$; Williams and Fehsenfeld (1991) report mean soil NO emissions for a deciduous forest in Tennessee of $0.28 \mathrm{ng}(\mathrm{N}) \mathrm{m}^{-2} \mathrm{~s}^{-1}$; Munger et al. (1996) use profile measurements of $\mathrm{NO}_{\mathrm{x}}$ to estimate maximum soil emissions from Harvard Forest of $3.5 \mathrm{ng}(\mathrm{N}) \mathrm{m}^{-2} \mathrm{~s}^{-1}$; Venterea et al. (2004) report mean soil NO emissions between 0.06 and $1.9 \mathrm{ng}(\mathrm{N}) \mathrm{m}^{-2} \mathrm{~s}^{-1}$ for forests in Maine and Virginia. Unpublished data in previous years from the vicinity of the PROPHET tower (see Alaghmand et al., 2011) indicated an average soil NO flux of around $0.7 \mathrm{ng}(\mathrm{N}) \mathrm{m}^{-2} \mathrm{~s}^{-1}$. From the available literature, if we consider a reasonable range in soil $\mathrm{NO}$ emissions at both locations of between 0.5 and $3 \mathrm{ng}(\mathrm{N}) \mathrm{m}^{-2} \mathrm{~s}^{-1}$ and disregard for the moment any canopy and/or chemical losses, this would translate into emission contributions to the measured net flux on the order of 0.8 to $5 \mathrm{pptm} \mathrm{s}^{-1} \mathrm{NO}_{\mathrm{x}}$. Since the observations suggest the net $\mathrm{NO}_{\mathrm{x}}$ flux is usually near zero, these 
emissions are either lost to deposition as $\mathrm{NO}_{2}$ or converted to higher $\mathrm{NO}_{\mathrm{y}}$ species $\left(\mathrm{HNO}_{3}, \mathrm{PANs}, \mathrm{RONO}_{2}\right)$. In the former case, this would make no net contribution to the observed $\mathrm{NO}_{\mathrm{y}}$ flux; in the latter case this would influence the observed $\mathrm{NO}_{\mathrm{y}}$ flux by contributing and upward flux component.

These observations confirm the need for further understanding the role of soil $\mathrm{NO}_{\mathrm{x}}$ emissions from forest systems, and the difficulty in constraining their magnitude. Soil $\mathrm{NO}_{\mathrm{x}}$ emissions and interactions with forest canopies remain poorly modelled, limited by the lack of data for model verification and accuracy in the available observations (Fowler et al., 2009). In addition to better precision in above-canopy flux measurements, vertical gradient observations and/or ideally dedicated soil chamber measurements would be required in the future.

\section{Conclusions}

$\mathrm{NO}_{\mathrm{y}}$ flux measurements above two comparable forests in North America have been presented. PROPHET and HFWR towers are both located within mixed forests that mark the transition between the deciduous and boreal forest, along $45^{\circ} \mathrm{N}$. Observations from HFWR were made for nine weeks between late July and early October 2011, while observations at PROPHET were made for three weeks between late July and mid-August of 2012.

Results show that $\mathrm{NO}_{\mathrm{y}}$ mixing ratios at PROPHET were slightly higher on average than at HFWR. Half-hour $\mathrm{NO}_{\mathrm{y}}$ fluxes were predominantly of deposition, and about twice as high at PROPHET than HFWR on average. In general, fluxes were on the same order of magnitude of previous observations elsewhere in North America. At both locations, we observed direct evidence of chemical divergence in NO and $\mathrm{NO}_{2}$ fluxes, and are unable to constrain soil emissions or $\mathrm{NO}_{2}$ deposition with these observations. Concurrent vertical profiles and soil chamber emission measurements would be beneficial in the future.

On an average daily basis, dry deposition of $\mathrm{NO}_{\mathrm{y}}$ resulted in inputs of 0.34 and $0.14 \mathrm{mg}(\mathrm{N}) \mathrm{m}^{-2} \mathrm{day}^{-1}$ at PROPHET and HFWR respectively, contributing approximately 40 and $22 \%$ of total nitrate inputs from wet and dry deposition during the period of observations. Organizing the flux measurements by wind direction observed from the towers showed a significant influence of transport on deposition rates. Both sites experience elevated dry deposition when flow is coming from the south. As a result, high-pollutant days have the potential to contribute disproportionately to overall deposition. Long-term measurements are therefore required to accurately assess the atmospheric nitrogen budget and reduce the influence of short-term variability of meteorology and transport conditions.

These observations can be used in future model evaluation studies, to bound the wet and dry deposition budgets in these regions. Further long-term measurements with speci- ated $\mathrm{NO}_{\mathrm{y}}$ observations, and $\mathrm{NO}_{\mathrm{x}}$ profile or soil chamber observations, would be desirable to provide even more detailed insight into model performance.

Acknowledgements. We gratefully acknowledge the support of collaborators from the HFWR-2011 and PROPHET-2012 field campaigns. Thanks to Sean Thomas, Jon Schurman, Alex Petroff, and Jon Wang (HFWR), and to Kevin McAvey, Steve Bertman, and Tim Starn (PROPHET). Thanks to Haliburton Forest and Wildlife Reserve Ltd for their support of our research at HFWR in 2011, and thanks to Mary Anne Carroll and Steve Bertman for the invitation to PROPHET in 2012. The authors also wish to thank Martin Buhr and David Tanner (Air Quality Design, Inc.) for their technical support. We also gratefully acknowledge the Natural Sciences and Engineering Research Council of Canada, and the Canada Foundation for Innovation, for funding.

Edited by: F. Keutsch

\section{References}

Alaghmand, M., Shepson, P. B., Starn, T. K., Jobson, B. T., Wallace, H. W., Carroll, M. A., Bertman, S. B., Lamb, B., Edburg, S. L., Zhou, X., Apel, E., Riemer, D., Stevens, P., and Keutsch, F.: The Morning $\mathrm{NO}_{\mathrm{x}}$ maximum in the forest atmosphere boundary layer, Atmos. Chem. Phys. Discuss., 11, 2925129282, doi:10.5194/acpd-11-29251-2011, 2011.

Ammann, C., Wolff, V., Marx, O., Brümmer, C., and Neftel, A.: Measuring the biosphere-atmosphere exchange of total reactive nitrogen by eddy covariance, Biogeosciences, 9, 4247-4261, doi:10.5194/bg-9-4247-2012, 2012.

Billesbach, D. P.: Estimating uncertainties in individual eddy covariance flux measurements: a comparison of methods and a proposed new method, Agr. Forest Meteorol., 151, 394-405, doi:10.1016/j.agrformet.2010.12.001, 2011.

Bonan, G.: Carbon cycle fertilizing change, Nat. Geosci., 1, 645646, 2008.

Buhr, M. P.: Solid-state light source photolytic nitrogen dioxide converter, United States Patent, 10/313827, 2007.

Carroll, M. A., Bertman, S. B., and Shepson, P. B.: Overview of the Program for Research on Oxidants: PHotochemistry, Emissions, and Transport (PROPHET) summer 1998 measurements intensive, J. Geophys. Res.-Atmos., 106, 24275-24288, doi:10.1029/2001JD900189, 2001.

Chaparro-Suarez, I. G., Meixner, F. X., and Kesselmeier, J.: Nitrogen dioxide $\left(\mathrm{NO}_{2}\right)$ uptake by vegetation controlled by atmospheric concentrations and plant stomatal aperture, Atmos. Environ., 45, 5742-5750, 2011.

De Sousa, A. N. F.: Wet and dry deposition of water-soluble inorganic ions, in particulare reactive nitrogen species, to Haliburton Forest, Ph.D. thesis, University of Toronto, Canada, 2010.

Fahey, D. W., Eubank, C. S., Hubler, G., and Fehsenfeld, F. C.: Evaluation of a catalytic reduction technique for the measurement of total reactive odd-nitrogen $\mathrm{NO}_{\mathrm{y}}$ in the atmosphere, J. Atmos. Chem., 3, 435-468, 1985.

Farmer, D. K. and Cohen, R. C.: Observations of $\mathrm{HNO}_{3}, \Sigma \mathrm{AN}$, $\Sigma \mathrm{PN}$ and $\mathrm{NO}_{2}$ fluxes: evidence for rapid $\mathrm{HO}_{\mathrm{x}}$ chemistry within 
a pine forest canopy, Atmos. Chem. Phys., 8, 3899-3917, doi:10.5194/acp-8-3899-2008, 2008.

Farmer, D. K., Wooldridge, P. J., and Cohen, R. C.: Application of thermal-dissociation laser induced fluorescence (TD-LIF) to measurement of $\mathrm{HNO}_{3}$, $\Sigma$ alkyl nitrates, $\Sigma$ peroxy nitrates, and $\mathrm{NO}_{2}$ fluxes using eddy covariance, Atmos. Chem. Phys., 6, 3471-3486, doi:10.5194/acp-6-3471-2006, 2006.

Finlayson, B. J., Pitts, N., and Atkinson, R.: Low-pressure gasphase ozone-olefin reactions - Chemiluminescence, kinetics and mechanisms, J. Amer. Chem. Soc., 96, 5356-5367, 1974.

Fitz, D., Bumiller, K., and Lashgari, A.: Measurement of NOY during the SCOS97-NARSTO, Atmos. Env., 37, S119-S134, 2003.

Flechard, C. R., Nemitz, E., Smith, R. I., Fowler, D., Vermeulen, A. T., Bleeker, A., Erisman, J. W., Simpson, D., Zhang, L., Tang, Y. S., and Sutton, M. A.: Dry deposition of reactive nitrogen to European ecosystems: a comparison of inferential models across the NitroEurope network, Atmos. Chem. Phys., 11, 2703-2728, doi:10.5194/acp-11-2703-2011, 2011.

Foken, T. and Wichura, B.: Tools for quality assessment of surfacebased flux measurements, Agr. Forest Meteorol., 78, 83-105, doi:10.1016/0168-1923(95)02248-1, 1996.

Fowler, D., Pilegaard, K., Sutton, M. A., Ambus, P., Raivonen, M., Duyzer, J., Simpson, D., Fagerli, H., Fuzzi, S., Schjoerring, J. K., Granier, C., Neftel, A., Isaksen, I. S. A., Laj, P., Maione, M., Monks, P. S., Burkhardt, J., Daemmgen, U., Neirynck, J., Personne, E., Wichink-Kruit, R., ButterbachBahl, K., Flechard, C., Tuovinen, J. P., Coyle, M., Gerosa, G., Loubet, B., Altimir, N., Gruenhage, L., Ammann, C., Cieslik, S., Paoletti, E., Mikkelsen, T. N., Ro-Poulsen, H., Cellier, P., Cape, J. N., Horvath, L., Loreto, F., Niinemets, U., Palmer, P. I., Rinne, J., Misztal, P., Nemitz, E., Nilsson, D., Pryor, S., Gallagher, M. W., Vesala, T., Skiba, U., Brueggemann, N., Zechmeister-Boltenstern, S., Williams, J., O'Dowd, C., Facchini, M. C., de Leeuw, G., Flossman, A., Chaumerliac, N., and Erisman, J. W.: Atmospheric composition change: ecosystemsatmosphere interactions, Atmos. Environ., 43, 5268-5350, doi:10.1016/j.atmosenv.2009.07.068, 2009.

Galloway, J. N., Aber, J. D., Erisman, J. W., Seitzinger, S. P., Howarth, R. W., Cowling, E. B., and Cosby, B. J.: The nitrogen cascade, BioScience, 53, 341-356, 2003.

Ganzeveld, L. N., Lelieveld, J., Dentener, F. J., Krol, M. C., Bouwman, A. J., and Roelofs, G. J.: Global soil-biogenic $\mathrm{NO}_{\mathrm{x}}$ emissions and the role of canopy processes, J. Geophys. Res.-Atmos., 107, 4298, doi:10.1029/2001JD001289, 2002.

Gao, W., Wesely, M. L., and Lee, I. Y.: A numerical study of the effects of air chemistry on fluxes of $\mathrm{NO}, \mathrm{NO}_{2}$, and $\mathrm{O}_{3}$ near the surface, J. Geophys. Res.-Atmos., 96, 18761-18769, doi:10.1029/91JD02106, 1991.

Gao, W., Wesely, M. L., and Doskey, P. V.: Numerical modeling of the turbulent-diffusion and chemistry of $\mathrm{NO}_{\mathrm{x}}, \mathrm{O}_{3}$, isoprene, and other reactive trace gases in and above a forest canopy, J. Geophys. Res.-Atmos., 98, 18339-18353, doi:10.1029/93JD01862, 1993.

Hills, A. and Zimmerman, P.: Isoprene measurement by ozoneinduced chemiluminescence, Anal. Chem., 62, 1055-1060, 1990.

Hogg, A. J.: Stomatal and non-stomatal fluxes of ozone, $\mathrm{NO}_{\mathrm{x}}$, and $\mathrm{NO}_{\mathrm{y}}$ to a northern mixed hardwood forest, Ph.D. thesis, University of Michigan, 2007.
Holland, E. A., Braswell, B. H., Sulzman, J., and Lamarque, J. F.: Nitrogen deposition onto the United States and western Europe: synthesis of observations and models, Ecol. Appl., 15, 38-57, doi:10.1890/03-5162, 2005.

Horii, C. V., Munger, J. W., Wofsy, S. C., Zahniser, M., Nelson, D., and McManus, J. B.: Fluxes of nitrogen oxides over a temperate deciduous forest, J. Geophys. Res.-Atmos., 109, D08305, doi:10.1029/2003jd004326, 2004.

Horii, C. V., Munger, J. W., Wofsy, S. C., Zahniser, M., Nelson, D., and McManus, J. B.: Atmospheric reactive nitrogen concentration and flux budgets at a Northeastern US forest site, Agr. Forest Meteorol., 136, 159-174, 2006.

Kliner, D.A.V., Daube, B. C., Burley, J. D., and Wofsy, S. C.: Laboratory investigation of the catalytic reduction technique for measurement of atmospheric NOy, J. Geophys. Res.-Atmos., 102, 10759-10776, 1997.

Lee, J. D., Moller, S. J., Read, K. A., Lewis, A. C., Mendes, L., and Carpenter, L. J.: Year-round measurements of nitrogen oxides and ozone in the tropical North Atlantic marine boundary layer, J. Geophys. Res.-Atmos., 114, D21302, doi:10.1029/2009JD011878 2009.

Lerdau, M. T., Munger, L. J., and Jacob, D. J.: Atmospheric chemistry - the $\mathrm{NO}_{2}$ flux conundrum, Science, 289, 2291-2293, doi:10.1126/science.289.5488.2291, 2000.

Magnani, F., Mencuccini, M., Borghetti, M., Berbigier, P., Berninger, F., Delzon, S., Grelle, A., Hari, P., Jarvis, P. G., Kolari, P., Kowalski, A. S., Lankreijer, H., Law, B. E., Lindroth, A., Loustau, D., Manca, G., Moncrieff, J. B., Rayment, M., Tedeschi, V., Valentini, R., and Grace, J.: The human footprint in the carbon cycle of temperate and boreal forests, Nature, 447, 848-850, 2007.

Massman, W. J.: The attenuation of concentration fluctuations in turbulent flow through a tube, J. Geophys. Res.-Atmos., 96, 15269-15273, 1991.

Min, K.-E., Pusede, S. E., Browne, E. C., LaFranchi, B. W., Wooldridge, P. J., Wolfe, G. M., Harrold, S. A., Thornton, J. A., and Cohen, R. C.: Observations of atmosphere-biosphere exchange of total and speciated peroxynitrates: nitrogen fluxes and biogenic sources of peroxynitrates, Atmos. Chem. Phys., 12, 9763-9773, doi:10.5194/acp-12-9763-2012, 2012.

Min, K.-E., Pusede, S. E., Browne, E. C., LaFranchi, B. W., Wooldridge, P. J., and Cohen, R. C.: Eddy covariance fluxes and vertical concentration gradient measurements of $\mathrm{NO}$ and $\mathrm{NO}_{2}$ over a ponderosa pine ecosystem: observational evidence for within canopy removal of $\mathrm{NO}_{\mathrm{x}}$, Atmos. Chem. Phys. Discuss., 13, 12437-12484, doi:10.5194/acpd-13-12437-2013, 2013.

Munger, J. W., Wofsy, S. C., Bakwin, P. S., Fan, S. M., Goulden, M. L., Daube, B. C., Goldstein, A. H., Moore, K. E., and Fitzjarrald, D. R.: Atmospheric deposition of reactive nitrogen oxides and ozone in a temperate deciduous forest and a subarctic woodland, 1. Measurements and mechanisms, J. Geophys. Res.-Atmos., 101, 12639-12657, 1996.

Munger, J. W., Fan, S. M., Bakwin, P. S., Goulden, M. L., Goldstein, A. H., Colman, A. S., and Wofsy, S. C.: Regional budgets for nitrogen oxides from continental sources: variations of rates for oxidation and deposition with season and distance from source regions, J. Geophys. Res.-Atmos., 103, 8355-8368, doi:10.1029/98JD00168, 1998. 
Neirynck, J., Kowalski, A. S., Carrara, A., Genouw, G., Berghmans, P., and Ceulemans, R.: Fluxes of oxidised and reduced nitrogen above a mixed coniferous forest exposed to various nitrogen emission sources, Environ. Pollut., 149, 31-43, doi:10.1016/j.envpol.2006.12.029, 2007.

Papale, D., Reichstein, M., Aubinet, M., Canfora, E., Bernhofer, C., Kutsch, W., Longdoz, B., Rambal, S., Valentini, R., Vesala, T., and Yakir, D.: Towards a standardized processing of Net Ecosystem Exchange measured with eddy covariance technique: algorithms and uncertainty estimation, Biogeosciences, 3, 571-583, doi:10.5194/bg-3-571-2006, 2006.

Pryor, S. C., Barthelmie, R. J., Jensen, B., Jensen, N. O., and Sorensen, L. L.: $\mathrm{HNO}_{3}$ fluxes to a deciduous forest derived using gradient and REA methods, Atmos. Environ., 36, 5993-5999, doi:10.1016/S1352-2310(02)00765-3, 2002.

Querino, C. A. S., Smeets, C. J. P. P., Vigano, I., Holzinger, R., Moura, V., Gatti, L. V., Martinewski, A., Manzi, A. O., de Araújo, A. C., and Röckmann, T.: Methane flux, vertical gradient and mixing ratio measurements in a tropical forest, Atmos. Chem. Phys., 11, 7943-7953, doi:10.5194/acp-11-79432011, 2011.

Reidmiller, D. R., Jaffe, D. A., Fischer, E. V., and Finley, B.: Nitrogen oxides in the boundary layer and free troposphere at the Mt. Bachelor Observatory, Atmos. Chem. Phys., 10, 6043-6062, doi:10.5194/acp-10-6043-2010, 2010.

Schmid, H. P., Su, H. B., Vogel, C. S., and Curtis, P. S.: Ecosystematmosphere exchange of carbon dioxide over a mixed hardwood forest in northern lower Michigan, J. Geophys. Res.-Atmos., 108, 4417, doi:10.1029/2002JD003011, 2003.

Seok, B., Helmig, D., Ganzeveld, L., Williams, M. W., and Vogel, C. S.: Dynamics of nitrogen oxides and ozone above and within a mixed hardwood forest in northern Michigan, Atmos. Chem. Phys., 13, 7301-7320, doi:10.5194/acp-13-7301-2013, 2013.

Sievering, H., Kelly, T., McConville, G., Seibold, C., and Turnipseed, A.: Nitric acid dry deposition to conifer forests: Niwot Ridge spruce-fir-pine study, Atmos. Environ., 35, 38513859, doi:10.1016/S1352-2310(01)00156-X, 2001.

Smeets, C. J. P. P., Holzinger, R., Vigano, I., Goldstein, A. H., and Röckmann, T.: Eddy covariance methane measurements at a Ponderosa pine plantation in California, Atmos. Chem. Phys., 9, 8365-8375, doi:10.5194/acp-9-8365-2009, 2009.

Sparks, J. P., Monson, R. K., Sparks, K. L., and Lerdau, M.: Leaf uptake of nitrogen dioxide $\left(\mathrm{NO}_{2}\right)$ in a tropical wet forest: implications for tropospheric chemistry, Oecologia, 127, 214-221, doi:10.1007/s004420000594, 2001.

Sparks, J. P., Walker, J., Turnipseed, A., and Guenther, A.: Dry nitrogen deposition estimates over a forest experiencing free air $\mathrm{CO}_{2}$ enrichment, Glob. Change Biol., 14, 768-781, doi:10.1111/j.1365-2486.2007.01526.x, 2008.

Suyker, A. E. and Verma, S. B.: Eddy-correlation measurement of $\mathrm{CO}_{2}$ flux using a closed-path sensor - theory and field-tests against an open-path sensor, Bound.-Lay. Meteorol., 64, 391407, doi:10.1007/BF00711707, 1993.

Templer, P. H., Pinder, R. W., and Goodale, C. L.: Effects of nitrogen deposition on greenhouse-gas fluxes for forests and grasslands of North America, Front Ecol. Environ., 10, 547-553, doi:10.1890/120055, 2012.
Thomas, R. Q., Canham, C. D., Weathers, K. C., and Goodale, C. L.: Increased tree carbon storage in response to nitrogen deposition in the US, Nat. Geosci., 3, 13-17, doi:10.1038/NGEO721, 2010.

Turnipseed, A. A., Huey, L. G., Nemitz, E., Stickel, R., Higgs, J., Tanner, D. J., Slusher, D. L., Sparks, J. P., Flocke, F., and Guenther, A.: Eddy covariance fluxes of peroxyacetyl nitrates (PANs) and $\mathrm{NO}_{\mathrm{y}}$ to a coniferous forest, J. Geophys. Res.-Atmos., 111, D09304, doi:10.1029/2005jd006631, 2006.

Venterea, R. T., Groffman, P. A., Castro, M. S., Verchot, L. V., Fernandez, I. J., and Adams, M. B.: Soil emissions of nitric oxide in two forest watersheds subjected to elevated $\mathrm{N}$ inputs, Forest Ecol. Manag., 196, 335-349, doi:10.1016/j.foreco.2004.03.028, 2004.

Vitousek, P. M., Aber, J. D., Howarth, R. W., Likens, G. E., Matson, P. A., Schindler, D. W., Schlesinger, W. H., and Tilman, D.: Human alteration of the global nitrogen cycle: sources and consequences, Ecol. Appl., 7, 737-750, doi:10.2307/2269431, 1997.

Webb, E. K., Pearman, G. I., and Leuning, R.: Correction of flux measurements for density effects due to heat and water-vapor transfer, Q. J. Roy. Meteor. Soc., 106, 85-100, doi:10.1002/qj.49710644707, 1980.

Wesely, M. L. and Hicks, B. B.: A review of the current status of knowledge on dry deposition, Atmos. Environ., 34, 2261-2282, doi:10.1016/S1352-2310(99)00467-7, 2000.

Wilczak, J. M., Oncley, S. P., and Stage, S. A.: Sonic anemometer tilt correction algorithms, Bound.-Lay. Meteorol., 99, 127-150, doi:10.1023/A:1018966204465, 2001.

Williams, E. J. and Fehsenfeld, F. C.: Measurement of soil-nitrogen oxide emissions at 3 north-american ecosystems, J. Geophys. Res.-Atmos., 96, 1033-1042, doi:10.1029/90JD01903, 1991.

Williams, E. J., Baumann, K., Roberts, J. M., Bertman, S.B. Norton, R. B., Fehsenfeld, C., Springston, S.R., Nunnermacker, L. J., Newman, L., Olszyna, K., Meagher, J., Hartsell, B., Edgerton, E., Pearson, J. R., and Rodgers, M. O.: Intercomparison of groundbased NOy measurement techniques, J. Geophys. Res.-Atmos., 103, 22261-22280, 1998.

Williams, E. J., Parrish, D. D., Buhr, M. P., Fehsenfeld, F. C., and Fall, R.: Measurement of soil NOx emissions in Central Pennsylvania, J. Geophys. Res.-Atmos., 93, 9539-9546, doi:10.1029/JD093iD08p09539, 1988.

Wolfe, G. M., Thornton, J. A., Yatavelli, R. L. N., McKay, M., Goldstein, A. H., LaFranchi, B., Min, K.-E., and Cohen, R. C.: Eddy covariance fluxes of acyl peroxy nitrates (PAN, PPN and MPAN) above a Ponderosa pine forest, Atmos. Chem. Phys., 9, 615-634, doi:10.5194/acp-9-615-2009, 2009.

Wolff, V., Trebs, I., Foken, T., and Meixner, F. X.: Exchange of reactive nitrogen compounds: concentrations and fluxes of total ammonium and total nitrate above a spruce canopy, Biogeosciences, 7, 1729-1744, doi:10.5194/bg-7-1729-2010, 2010.

Xue, L. K., Wang, T., Zhang, J. M., Zhang, X. C., Deliger, Poon, C. N., Ding, A. J., Zhou, x. H., Wu, W. S., Tang, J., Zhang, Q. Z., and Wang, Q. X.: Source of surface ozone and reactive nitrogen speciation at Mount Waliguan in western China: New insights from the 2006 summer study, J. Geophys. Res.Atmos., 116, D07306, doi:10.1029/2010JD014735, 2011.

Zhang, L., Brook, J. R., and Vet, R.: A revised parameterization for gaseous dry deposition in air-quality models, Atmos. Chem. Phys., 3, 2067-2082, doi:10.5194/acp-3-2067-2003, 2003. 
Zhang, L., Vet, R., O’Brien, J. M., Mihele, C., Liang, Z., and Wiebe, A.: Dry deposition of individual nitrogen species at eight Canadian rural sites, J. Geophys. Res.-Atmos., 114, D02301, doi:10.1029/2008JD010640, 2009.

Zhang, L., Jacob, D. J., Knipping, E. M., Kumar, N., Munger, J. W., Carouge, C. C., van Donkelaar, A., Wang, Y. X., and Chen, D.: Nitrogen deposition to the United States: distribution, sources, and processes, Atmos. Chem. Phys., 12, 4539-4554, doi:10.5194/acp-12-4539-2012, 2012.
Zhou, X., Zhang, N., TerAvest, M., Tang, D., Hou, J., Bertman, S. Alaghman, M., Shepson, P. B., Carroll, M. A., Griffith, S., Dusanter, S., Stevens, P. S.: Nitric acid photolysis on forest canopy surface as a source for tropospheric nitrous acid, Nature Geoscience, 4, 440-443, doi:10.1038/ngeo1164, 2011. 